Article

\title{
Sustainability Assessment of Smallholder Agroforestry Indigenous Farming in the Amazon: A Case Study of Ecuadorian Kichwas
}

\author{
Marco Heredia- $R^{1,2, *(\mathbb{D})}$, Bolier Torres ${ }^{2,3}\left(\mathbb{D}\right.$, Jhenny Cayambe ${ }^{4}\left(\mathbb{D}\right.$, Nadia Ramos ${ }^{5}(\mathbb{D}$, \\ Marcelo Luna ${ }^{6}$ (D) and Carlos G. H. Diaz-Ambrona ${ }^{1}$ (D) \\ 1 AgSystems, Ceigram, itdUPM, Centro de Innovación en Tecnología para el Desarrollo, \\ Universidad Politécnica de Madrid (UPM), 28040 Madrid, Spain; carlosgregorio.hernandez@upm.es \\ 2 Universidad Regional Amazónica IKIAM, Km 7 Vía Muyuna, Tena 150150, Ecuador; \\ bolier.torres@ikiam.edu.ec \\ 3 Departamento de Ciencias de la Vida, Universidad Estatal Amazónica (UEA), Pastaza 160101, Ecuador \\ 4 School of Agricultural and Environmental Sciences, Pontificia Universidad Católica del Ecuador Sede \\ Ibarra (PUCESI), Imbabura 100112, Ecuador; jmcayambe@pucesi.edu.ec \\ 5 Andean University Simon Bolivar, Toledo N22-80, Quito 170143, Ecuador; nadiaramosr@gmail.com \\ 6 Departamento de Ciencias de la Tierra, Universidad Estatal Amazónica (UEA), Pastaza 160101, Ecuador; \\ mluna@uea.edu.ec \\ * Correspondence: mageher@gmail.com
}

Received: 7 November 2020; Accepted: 10 December 2020; Published: 15 December 2020

\begin{abstract}
In the Amazon, the Yasuní Biosphere Reserve (YBR) is considered a natural and cultural diversity hotspot. It is populated by several indigenous groups, including the Kichwa, who are characterized by their traditional systems of production, which are a means of subsistence and socio-ecological integration. The objective of this research was to evaluate the sustainability of small farmers who use a traditional agroforestry system (chakra) within the buffer, transition, and core zones of the YBR. We conducted 133 interviews with Kichwa heads of households. The socio-demographic structure and distribution were identified, and the response-inducing sustainability evaluation (RISE) methodology was used to evaluate chakra sustainability according to social, economic, and ecological dimensions, expressed using 10 indicators from 50 parameters, valued from 0 (worst case) to 100 (best case). The results are expressed in a polygon, defined by the areas: (1) good performance, (2) medium performance, and (3) poor performance. We employed the multivariate classification hierarchical cluster technique and analysis of variance (ANOVA) to identify dissimilarities between groups of chakras and the existence of statistical differences, respectively. Among the studied indigenous Kichwas, a pyramidal structure progressive type was identified, which is characteristic of young populations and the nonexistence of significant differences between the RISE indicators and chakras. The lowest-scoring indicators using the RISE guidelines were: use of materials and environmental protection, animal production, economic viability and chakra administration. We provide suggestions for decision makers who support Kichwa populations in socio-productive management with sustainability goals. We to taking actions on the indicators identified with high priority to improve the sustainability in the chakras and sociodemographic dynamics.
\end{abstract}

Keywords: hotspot; natural resources; sustainable agriculture; Yasuní

\section{Introduction}

The biological and cultural richness of the tropics is recognized globally. Worldwide, it is estimated that there are approximately 300 million indigenous people who belong to 5000 different cultures, 
representing between $80 \%$ and $90 \%$ of the world's cultural diversity [1]. They are also called tribal, aboriginal, or autochthonous peoples; they are located in various ecosystems, particularly in the tropics [2]. In many cases, national minorities may meet one or more of the following criteria: (a) they are descendants of the original inhabitants of an ancestral territory; (b) they are peoples of the ecosystem, such as cultivators, shepherds, hunter-gatherers, fishers, permanent or itinerant artisans, etc.; (c) they practice a form of small-scale rural production; (d) they organize their lives at a community level; (d) they share common traditional clothing, moral values, and identifying characteristics; (e) they have a custodial and non-materialistic attitude based on a symbolic exchange with nature; (f) some are subjugated by a dominant culture, society, and economy, and others remain isolated from market economies, preserving their culture and social dynamics; and (g) they consist of individuals who subjectively consider themselves to be indigenous [3].

The Western Amazon includes parts of Bolivia, Colombia, Ecuador, Peru, and western Brazil. It is one of the most biodiverse areas on the planet for many taxa, which include plants, insects, amphibians, birds, and mammals [4-9]. The region maintains large areas of intact tropical humid forest and has a high probability of stable climatic conditions in the face of global warming [10]. The Western Amazon is also home to many indigenous ethnic groups, including some of the world's last peoples living in voluntary isolation [11-13]. Ecuador has a cultural heritage with an estimated one million people self-identifying as indigenous [14]. In the Ecuadorian Amazon Region (EAR), there are currently 11 officially identified nationalities, one of which is the Amazonian Kichwa, the most populous ethnic group in this region. The EAR has been inhabited since before the Hispanic conquest by the Kichwa and other indigenous peoples $[15,16]$. Since the second half of the 19th century, these populations have increased due to rubber plantations [17]. However, their large-scale environmental transformation began in the 1970s with the intensification of oil exploitation, highway expansion, and colonization [18], which led to the division of ancestral lands and the displacement and disintegration of indigenous nationalities [19]. Later, the construction of roads, initially to facilitate oil activities, brought the small-scale agricultural colonization of migrant settlers, who were also pushed by government land tenure policies [20]. These processes transformed the cultural, social, and, to some extent, the agricultural context of the Kichwa populations given their territorial displacement as well as their contact with societies based on the market economy [21]. With this intervention by external agents in the territory, new strategies for living were created such as: participation in salaried jobs, the purchase of manufactured products, the use of government services, and participation in political activism. In the agricultural context, access to markets provoked new agricultural practices [22-24], such as the expansion of monocultures like cacao (Theobroma bicolor L.) and especially for the sale of small-scale agricultural and livestock products [25]. This caused the rapid expansion of the agricultural frontier and consequent deforestation [26], diminishing the quantity and quality of ecosystem services [27], which have been used ancestrally as a means of livelihood.

The Amazonian Kichwa populations have also been characterized by their agricultural systems, having practiced the traditional system called chakra for thousands of years. This system was initially oriented toward subsistence, integrated with the cultivation of basic foodstuffs, such as manioc (Manihot esculenta Crantz), plantain banana (Musa paradisiaca L.), peach palm (Bactris gasipaes Kunth) etc., as well as medicinal plants [28,29]. It is characterized by its high level of diversity [30] and its ability to provide security and sovereignty in terms of food and health [31-33]. The chakra plots in the Northern Ecuadorian Amazon range from 0.05 to 3.0 ha [30,34,35], have high levels of ecological and social integration [36-38], and can mitigate both the impact of population growth in the Amazon [29] and the effects of climate change [39].

The need is urgent for greater agricultural sustainability [40]; comprehensive responses are required to understand the complex dynamics between social, economic, and ecological sustainability [41,42]. In 2015, the United Nations plenary approved the 2030 agenda, converging the development, environment, and climate agendas. The agenda includes 17 sustainable development goals (SDGs) that must be met by 2030, unlike the previous sectorial and regional goals, such as the Millennium 
Development Goals for the period 2000-2015, which only directly affected developing countries. This new agenda is for everyone and for a global world. This means that in the coming years, all political actions and business strategies, and especially private ones, must be aligned with the achievement of those objectives. In the field of agriculture, agricultural and environmental policies will be aligned with the agenda, especially in the field of sustainability. The specific related goals include SDG 15: Life of terrestrial ecosystems, in which the Amazon biome is a main exponent; the scope of SDG 1: End poverty in all its forms; and SDG 2: Zero hunger should be allowed, in coexistence with local populations [43]. Assessing agricultural sustainability is one of these responses. Although capturing the systemic complexity of sustainability through assessment is difficult, it is warranted by the attention of policy makers beyond crop productivity to include dimensions of human well-being and ecological soundness [44,45]. Sustainability is a multidimensional concept [46] of a dignified life for the present without compromising a dignified life for future generations or threatening the natural environment and endangering the global ecosystem [47]; its evaluation is an important process in promoting the concept of sustainable agricultural systems [48,49].

To understand the transition toward more sustainable production, a variety of tools have been developed to obtain information on the sustainability performance of production $[50,51]$. Indicator-based sustainability assessment tools require the management of a wide variety of information types, parameters, and uncertainties [52], and vary in scope (geographic and sectorial), target group (farmers or policy makers), selection of indicators, aggregation, weighting methods, and time required for their execution $[50,51,53]$. Although many emphasize the importance of integrating social, economic, and environmental issues into sustainability assessment tools, environmental issues and tools generally receive more attention $[50,51,54-56]$. The results of sustainability assessment tools should be seen as a starting point for discussion, reflection, and learning [57].

Several tools are available for the evaluation of sustainability based on indicators: farm sustainability indicators (IDEA) [58], sustainability assessment of food and agriculture systems (SAFA) [59], response-inducing sustainability evaluation (RISE) [60], and others [61,62]. The IDEA tool was developed in France in 1998. Its analysis is at the farm level and it represents an approach based on principles; methodological indicators can be added [58]. SAFA is an open process methodology. According to the guidelines of the Food and Agriculture Organization of the United Nations (FAO), it is used as a self-assessment tool for food producers and manufacturers [59]. The justifications for the selection of indicators have been documented, and the integration problems between scales have been considered. It is not possible to add indicators, and the validation of the indicators is based on comparison and expert evaluation [63]. RISE is an easy-to-use tool that covers all dimensions of sustainability [57] and uses principles-based approaches; RISE presents both numerical and graphical results [51]. RISE is the best compared to other tools for sustainability assessment in terms of scientific robustness, feasibility, utility, influence, spatial applicability, and adaptability [52]. RISE has been used in various countries such as Poland, Spain, Kenya, and Canada, and in different evaluation scenarios (Table 1).

Table 1. Evaluation of sustainability using the response-inducing sustainability evaluation (RISE) methodology.

\begin{tabular}{cccc}
\hline Evaluation Scenario & Country & Indigenous Peoples and/or Small Producers & References \\
\hline Family farming & Sweden & No & {$[64]$} \\
Organic and conventional farms & Poland & No & {$[65]$} \\
Indigenous agriculture & Ecuador & Yes & {$[66]$} \\
Organic farms & Denmark & No & {$[67]$} \\
Agricultural and livestock production & Ethiopia & Yes & {$[68]$} \\
Tea plantation & India & Yes & {$[69]$} \\
Agricultural production & Spain & No & {$[70]$} \\
Coffee cultivation & Brazil & Yes & {$[71]$} \\
\hline
\end{tabular}


Sustainability assessment tools can provide support for decision making in production systems and may, therefore, significantly impact their sustainable development $[53,72]$. The availability and quality of data, time and budget requirements, as well as factors related to unknown terminology and ease of use of use and accessibility of the tool, influence the perception of small producers about the relevance of the tool and, consequently, whether they decide to use it $[53,73,74]$.

In this study, our aim was to assess the sustainability of small farms using the traditional agroforestry system (chakra) in the Ecuadorian Amazon, with the objective of understanding traditional knowledge about the farming system and to explore and discuss possible improvements.

\section{Materials and Methods}

\subsection{Geographical Location}

We focused on the Kichwa populations settled along the Napo River, in the north of the Yasuní Biosphere Reserve (YBR). This indigenous group is the result of inter-ethnic relations with ancestral populations in the area: Quijos, Záparos, Omaguas, Tucanos, Shuar, Achuar, Siona, Secoya, and Highland Kichwas and Peruvian Quechuas [36]. The Kichwa of this region are the most numerous indigenous populations in the EAR $(60,000$ inhabitants) $[37,38]$. Those residing in the Yasuní National Park (YNP) present a type of grouping based on associations that cohabit communal territories, associations, and federations [39]. They speak Runa Shimi, a dialect based on Kichwa and Spanish. Their identities are complex and overlap with other indigenous and white settler groups.

The study was conducted in two sectors, A and B, located in the YBR, which is considered one of the areas with the greatest biological and cultural biodiversity on the planet [75-78], including the YNP, Waorani Ancestral Territory (WAT), Tagaeri Taromenane Intangible Zone (TTIZ), and the Fringe of Diversity and Life (FDL), located in the EAR. Ecuador is 1 of 17 megadiverse countries [79,80] (Figure 1). The YBR was announced by UNESCO in 1989; it is located in the provinces of Orellana (51.96\%), Pastaza (39.40\%), and Napo (8.64\%), between the Napo and Curaray Rivers [81]. The predominant ecosystem is lowland evergreen forest in the Napo-Curaray (BsTa02) [82], the temperature ranges from 24 to $27^{\circ} \mathrm{C}$, rainfall is $3200 \mathrm{~mm} /$ year, relative humidity ranges from $80 \%$ to $94 \%$, and the soils are relatively young and are generated by fluvial sediments from the erosion of the Andes [83].
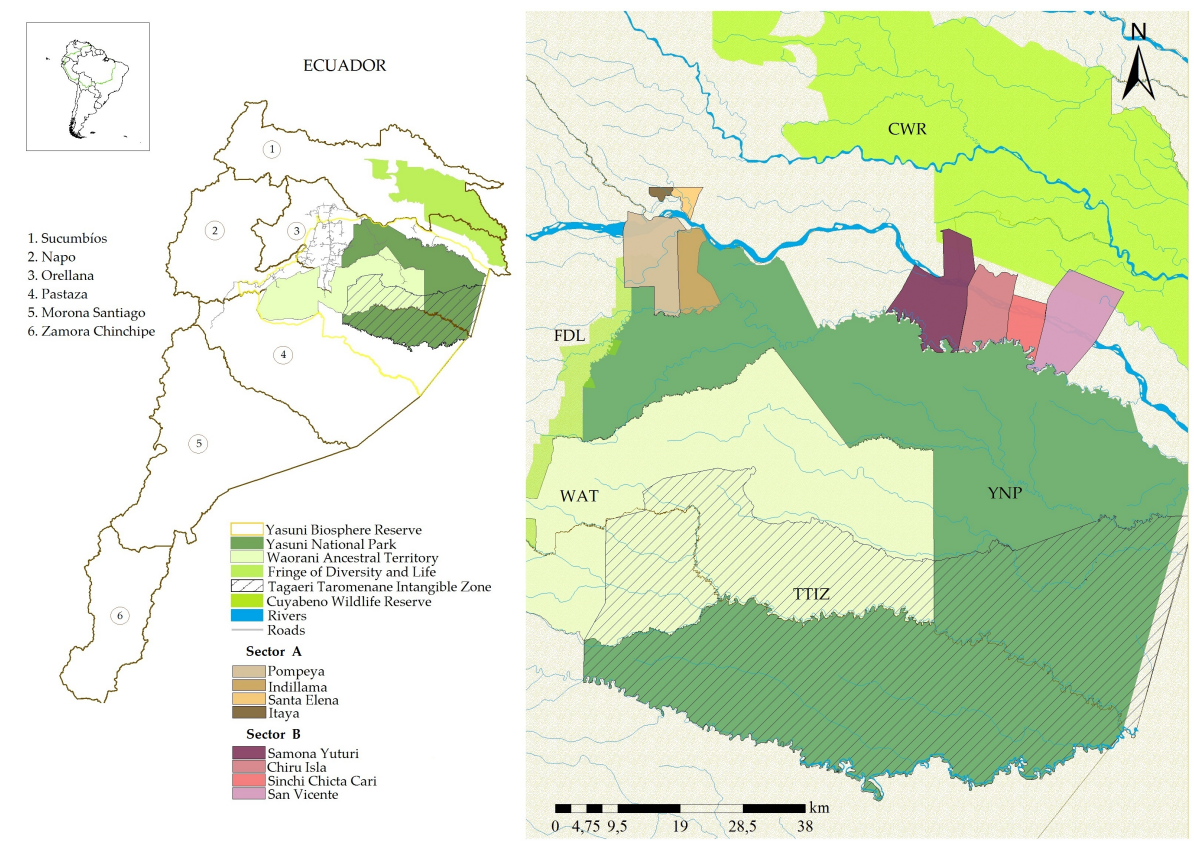

Figure 1. Sectors A and B located in the north of the Yasuní Biosphere Reserve (YBR) in the Ecuadorian Amazon region. 


\subsection{Sampling and Data Collection}

In the sectors identified, sampling was performed using the reference chain or snowball methodology [84], given the difficulty of constructing a sampling frame due to the scarcity of demographic information in the intervention zone and the complex logistics for traveling to and mobilization through the communities. This method begins with one interviewee, who gives the researcher the name of at least one other potential interviewee. This interviewee, in turn, provides the name of at least one other potential interviewee, etc., with the sample growing like a rolling snowball if more than one reference is provided per interviewee $[85,86]$. In the initial phase of the survey, participants expressed their concern that local and international institutions would cut social and agricultural programs due to participation in the study. In this situation, a signed informed consent form was not used, but with the support of the German Agency for Development Cooperation (GIZ-Ecuador), all approaches were made to producers and the principles of ethical research were explicitly applied [87], discussing the objectives, risks, methodology, and schedule of the study with members of each community. One of the pillars of our positive relationship with the participants was the presentation of the results of the questionnaire. The restitution of results is an ethical duty that is often overlooked when conducting research on human beings, especially when indigenous communities participate $[88,89]$.

\subsection{Characterization and Sociodemographic Indices}

Surveys were conducted with 133 Kichwa households with chakras. They were distributed by sector. In sector A (61), the surveys occurred in the communities of Pompeya (35), Indillama (10), Santa Elena (4), and Itaya (12). In sector B (72), they were conducted in the communities of Samona Yuturi (14), Chiru Isla (31), Sinchi Chicta Cari (15), and San Vicente (12). The average area of the chakras was 0.5 ha in 60 ha of titled land per household.

We studied the Kichwa population structure and its distribution by sex and age from a population pyramid (statistical representation) [90] to examine its implications with traditional production systems [91]. We calculated the following indices: (1) proportion of young population $(<14$ years) $\left(P_{\text {young people }}\right) ;(2)$ proportion of adult population (between 15 and 64 years, $\left.P_{\text {adults }}\right) ;(3)$ ratio of children to women, defined as the number of children under 5 years of age for each woman of reproductive age $(R)$; (4) the ratio of men, consisting of the ratio of men for every 100 women in a given population, considered as the first indicator for analyzing the distribution by sex in the population (R.M.); (5) youth dependency ratio, which is the relationship between the potentially dependent age population $(<15$ years) and the potentially active age population (between 15 and 64 years, $\left(I_{d j}^{t}\right) ;(6)$ the structure index of the active age population, which is the relationship between the population from 40 to 64 years and the population from 15 to 39 years $\left(I_{r}\right)$; and (7) the rate of change of the active age population $\left(I_{r}^{t}\right)$, which is the relationship between the population from 60 to 64 years and the population from 15 to 19 years [90-94], as follows:

$$
\begin{gathered}
P_{\text {young people }}=\frac{P_{0-14}}{P} \times 100 \\
P_{\text {adults }}=\frac{P_{15-64}}{P} \times 100 \\
R=\frac{P_{0-4}}{P_{M .15-49}} \text { children per woman } \\
\text { R.M. }=\frac{P_{\text {men }}}{P} \times 100 \\
I_{d j}^{t}=\frac{P_{<15}^{t}}{P_{15-64}^{t}} \times 100
\end{gathered}
$$




$$
\begin{aligned}
& I_{r}=\frac{P_{15-64}^{t}}{P_{15-39}^{t}} \times 100 \\
& I_{r}^{t}=\frac{P_{60-64}^{t}}{P_{15-19}^{t}} \times 100
\end{aligned}
$$

\subsection{Assessment of Agricultural Sustainability}

The RISE methodology was applied to holistically evaluate the sustainability of the traditional agroforestry system (chakra). The dimensions considered were economic, social, and ecological [95-99], which allowed us to analyze and compare the degree of sustainability between the chakras. This methodological tool is characterized by the balance between the simplicity of the analysis, the complexity of reality and the transparency of the results $[60,97]$. RISE seeks to create a tangible evaluation based on science that allows for the beginning of the creation of measures to improve sustainability $[98,99]$ and to initiate a constructive dialogue between producers and processors to spread the philosophy of sustainable production [96-98]. The methodological process began with an interview of the owner of a chakra. The RISE questionnaire was designed with three types of questions: open, drop-down list, and Boolean. The structural index of the questionnaire was divided into three stages: (A) preparation of the field visit to the chakras, containing general questions; (B) questions for the field visit, containing questions with qualitative and quantitative data that were collected during the RISE interview; and (C) comments, a space where notes can be transcribed about the questions or observations during the visit to the chakra. The duration of the questionnaire was 95 min [98].

For the systematization and analysis of the data of the conglomerate of the communities and the holistic evaluation, we used RISE 3.0 Software [99], developed by the Swiss College of Agriculture (SHL), based on the 10 standard indicators according to 50 parameters (Table 2), valued from 0 (worst case) to 100 (best case). As a result, a sustainability polygon was issued, defined by the following areas: (1) good yield, green coloration (66.66-100); (2) average yield, yellow coloration (33.34-66.65); and (3) bad yield, red coloration (0-33.33). The qualification values in the RISE method are fixed and cannot be changed. The red line superimposed on the polygon indicates the degree of sustainability per indicator, which is based on the arithmetic average of four to seven parameters that have the same weight [98].

Table 2. Indicators and parameters used in this study based on response-inducing sustainability evaluation (RISE) 3.0 methodology.

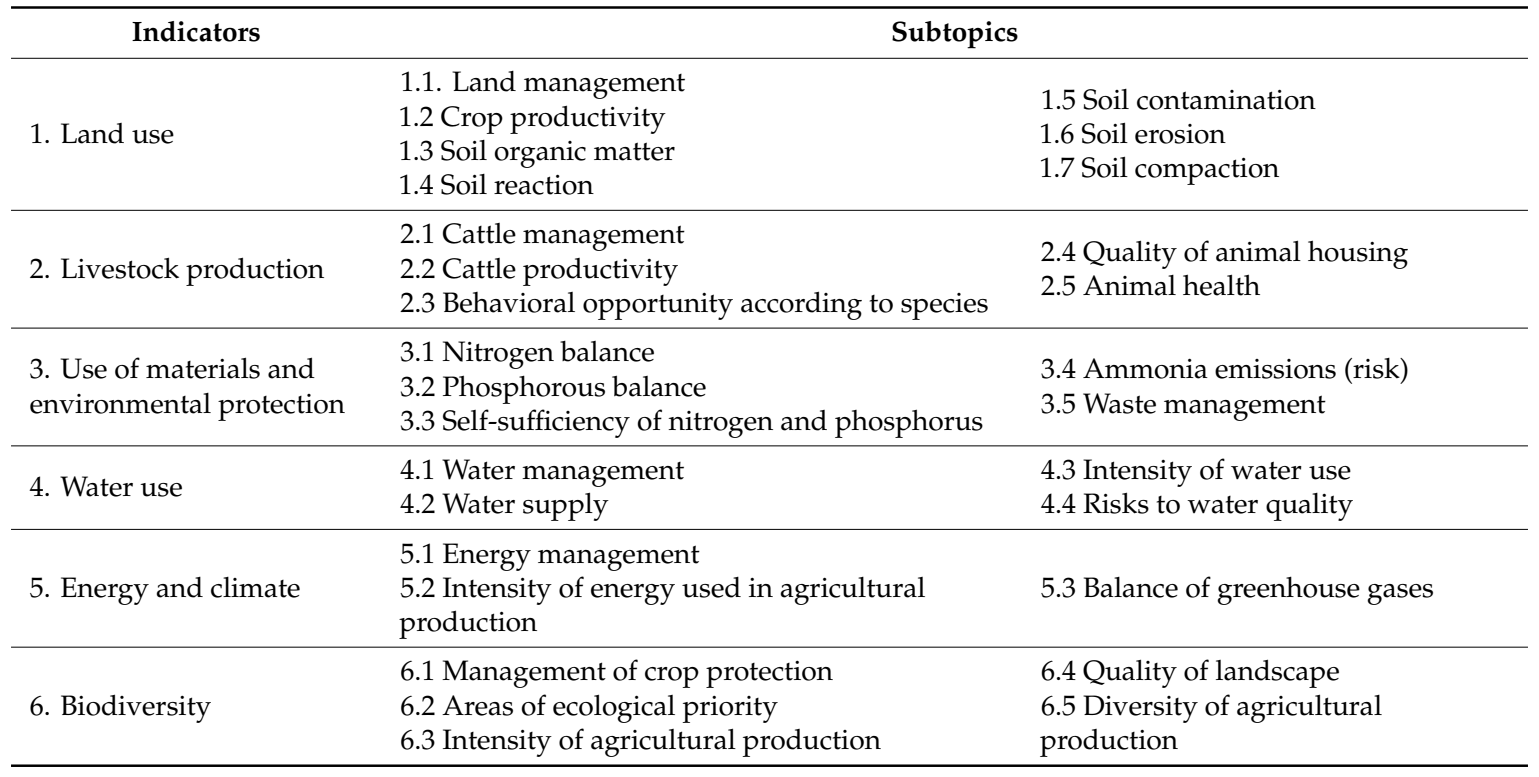


Table 2. Cont.

\begin{tabular}{|c|c|c|}
\hline Indicators & Sub & \\
\hline 7. Working conditions & $\begin{array}{l}\text { 7.1 Staff management } \\
\text { 7.2 Working hours }\end{array}$ & $\begin{array}{l}\text { 7.3 Health and safety } \\
\text { 7.4 Salary and income levels }\end{array}$ \\
\hline 8. Quality of life & $\begin{array}{l}\text { 8.1 Occupation and education } \\
\text { 8.2 Financial situation } \\
\text { 8.3 Social relations }\end{array}$ & $\begin{array}{l}\text { 8.4 Personal freedom and values } \\
8.5 \text { Health }\end{array}$ \\
\hline 9. Economic viability & $\begin{array}{l}\text { 9.1 Liquidity reserve } \\
\text { 9.2 Level of debt } \\
\text { 9.3 Economic vulnerability } \\
\text { 9.4 Secureness of household livelihoods }\end{array}$ & $\begin{array}{l}\text { 9.5 Cash flow, sales volume ratio } \\
\text { 9.7 Exhaustion of the capacity to serve } \\
\text { the capital of others (payment of } \\
\text { interest and amortization) }\end{array}$ \\
\hline 10. Administration & $\begin{array}{l}\text { 10.1 Strategies and planning } \\
\text { 10.2 Guarantee of supply and performance }\end{array}$ & $\begin{array}{l}\text { 10.3 Tools for planning } \\
\text { and documenting } \\
\text { 10.4 Administration of quality } \\
\text { 10.5 Cooperation with others }\end{array}$ \\
\hline
\end{tabular}

\subsection{The State and Driving Force for Calculating the Degree of Sustainability}

Each indicator contains parameters that describe the state of the system (S) and the driving force (D) within the system, leading it in a certain direction of development. S indicates the current condition of each specific indicator, and $\mathrm{D}$ is a measure of estimated pressure exerted by the agricultural system on the specific indicator [60]. The state parameters have a value between 0 (worst case) and 100 (best case). The driving force parameters are also calculated using a range of 0 to 100 , but since they are valued as a negative pressure in the system, 0 represents the best case and 100 the worst case (the highest pressure).

The degree of sustainability (DS) is calculated as the difference between the state (S) and the driving force (D); DS = S-D (Figure 2). Considering the S and D parameters not only allows for the creation of a static picture of the current situation; it reveals the development trends of the system. Therefore, the RISE evaluation provided an analytical snapshot of the chakra situation while describing some aspects of the dynamics that change the system over time. The assessment of the driving force allowed us to understand and highlight the trends and threats that can be decisive for the concept of operational sustainability.

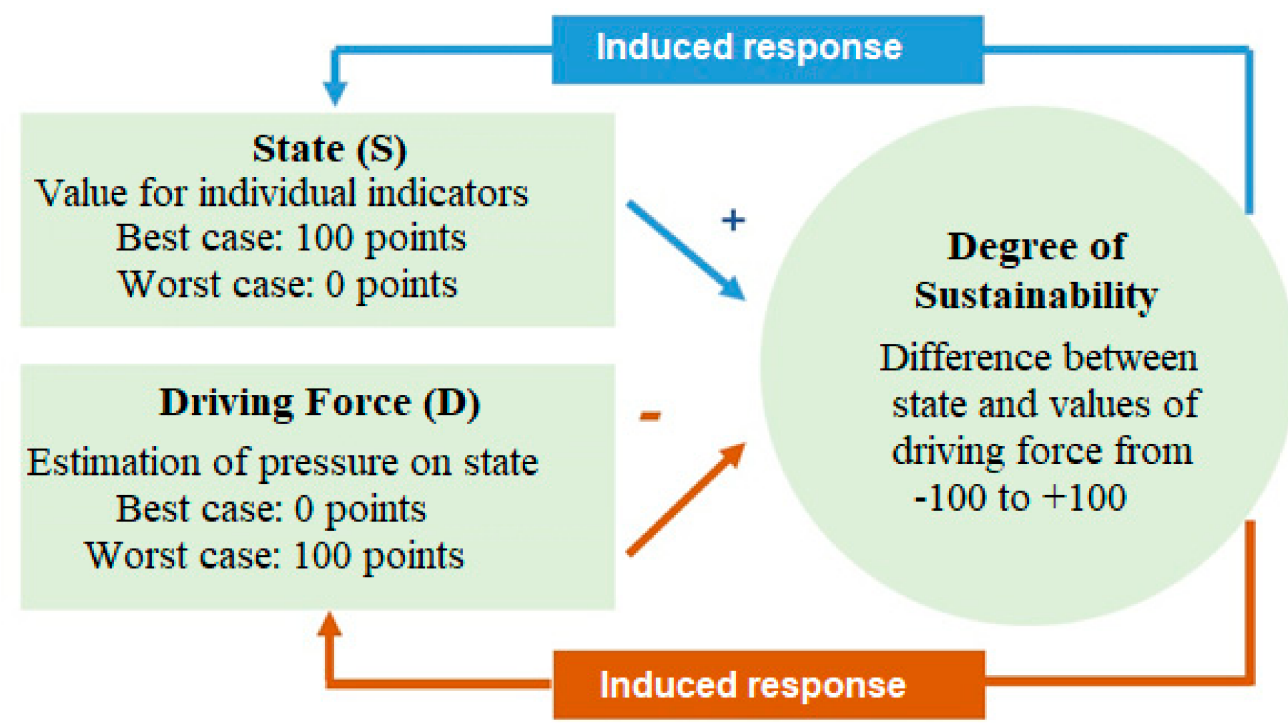

Figure 2. Methodology for calculating the degree of sustainability according to the RISE methodology. 


\subsection{Hierarchical Cluster Analysis}

The statistical analysis was conducted using the multivariate classification hierarchical cluster technique. This is a mathematical method that is included in multivariate statistics. Multivariate analysis is the branch of statistical analysis that studies, analyzes, represents, and interprets the data resulting from the observation of $p>1$ statistical variables on a sample of $\mathbf{n}$ individuals. It focuses on the simultaneous investigation of two or more characteristics (variables), measured on a set of individuals [100]. Hierarchical cluster analysis is mainly used for the formation of groups starting with the basic unit of the objective (BUO), according to the similar characteristics from the similarities or dissimilarities that are presented between pairs of these BUOs in the evaluated characteristics [101]. The hierarchical methodology deals with the grouping of clusters to form a new group, starting with groups as existing individuals in the study and grouping them to form all the cases in the same group [102].

All the sustainability variables defined by the RISE evaluation framework were used, applying the Euclidean squared distance as a similarity criterion, which is a measurement that is affected by the differences in metrics between the variables [100]. It is a measurement of dissimilarity: its minimum value is 0 , but it has no maximum value [101]. We also employed the Ward grouping method for hierarchically forming the groups and agglomerates by minimizing the intra-group variation. It tends to generate small but very balanced conglomerates [103] and, at each step of the agglomeration process, uses the distance between classes that meets the objective of joining [104,105].

The data were organized in an Excel spreadsheet (version 19.0, Microsoft, Redmond, United States), using the SPSS version 22 statistical software (IBM, Armonk, United States) [106] to evidence the history of clusters, where the groups to be formed were selected according to the dissimilarity index. The resulting dendrograms are presented for analysis of the sectors in an individual and united way according to the owner of the chakra and analysis of variance (ANOVA) was used to identify the existence of significant differences (0.05) between groups of means.

\section{Results}

\subsection{Sociodemographic and Agricultural Characterization}

The Kichwa population in the study area was $48.5 \%$ men and $51.5 \%$ women ( 726 total). The average age for men was 27 years and the average for women was 29. The proportion of young men was $17.7 \%$ and women, $22.8 \%$; adult men comprised $30.7 \%$ and women, $28.6 \%$ (Figure 3 ). The ratio of children to women was $0.45 \%$, while the ratio of men was $48 \%$. The youth dependency index was $68 \%$, the structural index of the working age population was $40 \%$, and the rate of change of the working age population was $4 \%$.

The following pattern was found in the evaluated sites: in sector A, the household composition varied between four and six people. In this sector, the Pompeya and Itaya communities reported at least one household with 10 individuals. In sector B, the household composition ranged from four to seven (Table 3) and the Sinchi Chicta Cari community reported a household with 11 individuals. The average household size in the communities studied was five individuals.

The average age of the heads of household was 42 years. The youngest head of the household (25 years) lived in the Sinchi Chicta Cari community. The youngest age range was between 25 and 34 years. In the communities of Pompeya, Chiru Isla, and San Vicente resides, the oldest head of the household was 60 years. The oldest age ranged from 44 to 60 years.

In the communities of Pompeya and Chiru Isla EL $8.57 \%$ and $3.23 \%$, respectively, completed the third level of education. In Itaya and San Vicente, $8.33 \%$ of the heads of household entered the third level of education but had not finished it. In sectors A and B, $19(31.31 \%)$ and $28(38.24 \%)$ heads of household had completed secondary education, respectively; in sectors A and B, 43 and 32 heads of household had completed basic education, respectively. 
With regards to land tenure, of the 133 heads of household surveyed, $88 \%$ (117 Kichwa indigenous) had deeds (legal land tenure) to their chakras. In the community of Santa Elena (sector A), all had deeds, whereas in the Chiru Isla community (sector B), 23\% did not have legal documentation for their land. On average in sectors $\mathrm{A}$ and $\mathrm{B}, 4 \%$ and $8 \%$ of the chakra owners, respectively, did not have deeds to their lands.

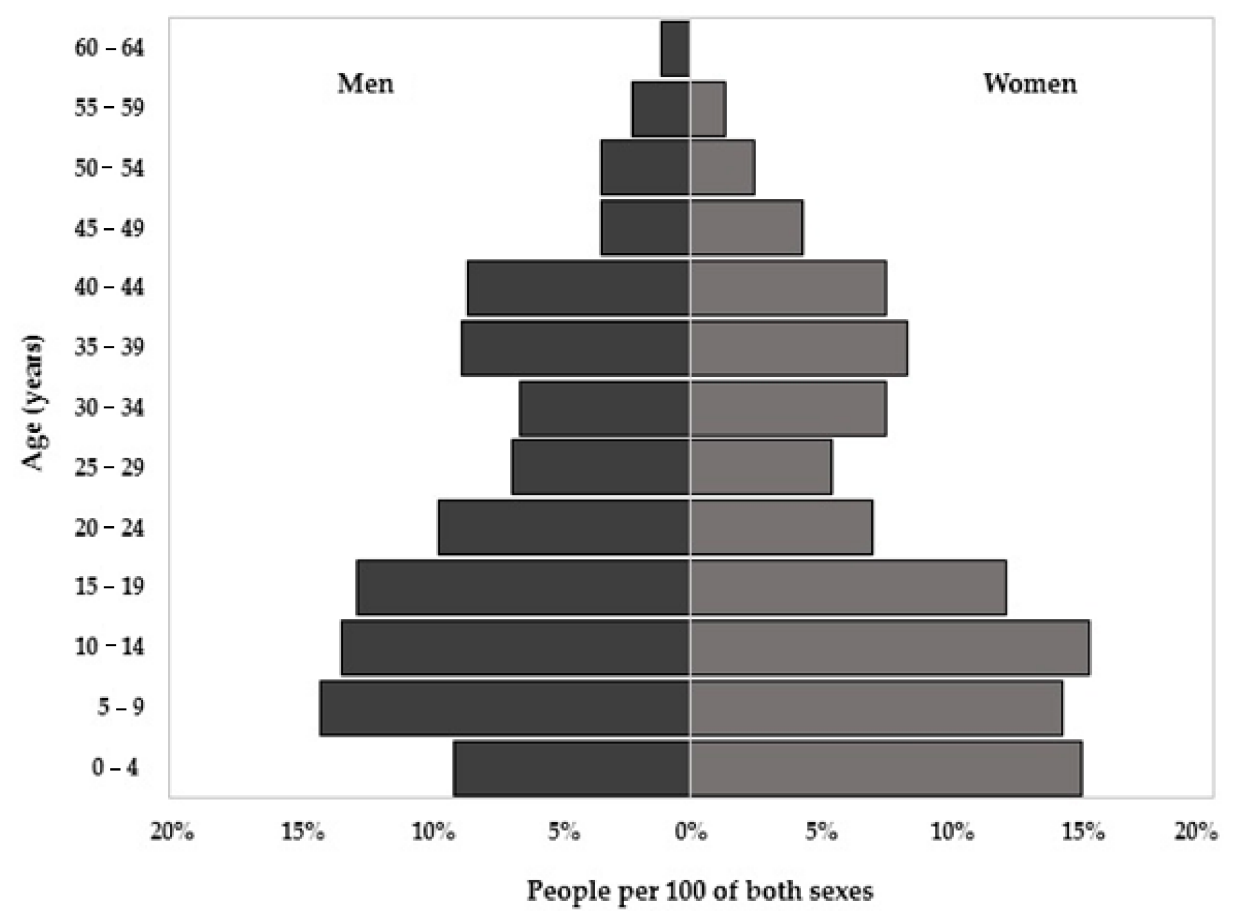

Figure 3. Population pyramid (progressive type) of Kichwas superimposed in the YBR in January 2018.

Table 3. Socio-demographic and agricultural characteristics of the Kichwa population by sector and communities in the north of the Yasuní Biosphere Reserve in the Ecuadorian Amazon region.

\begin{tabular}{|c|c|c|c|c|c|c|c|c|c|}
\hline \multirow{2}{*}{\multicolumn{2}{|c|}{ Variables }} & \multicolumn{4}{|c|}{ Sector A } & \multicolumn{4}{|c|}{ Sector B } \\
\hline & & \multirow{2}{*}{$\begin{array}{c}\text { Pompeya } \\
5 \\
(2.18)\end{array}$} & \multirow{2}{*}{$\begin{array}{c}\text { Indillama } \\
4 \\
(2.37)\end{array}$} & \multirow{2}{*}{$\begin{array}{c}\text { Santa } \\
\text { Elena } \\
4 \\
(2.16)\end{array}$} & \multirow{2}{*}{$\begin{array}{c}\text { Itaya } \\
6 \\
(2.20)\end{array}$} & \multirow{2}{*}{$\begin{array}{c}\text { Samona } \\
\text { Yuturi } \\
6 \\
(2.16)\end{array}$} & \multirow{2}{*}{$\begin{array}{c}\text { Chiru } \\
\text { Isla } \\
5 \\
(2.17)\end{array}$} & \multirow{2}{*}{$\begin{array}{c}\begin{array}{c}\text { Sinchi } \\
\text { Chicta } \\
\text { Cari }\end{array} \\
4 \\
(2.91)\end{array}$} & \multirow{2}{*}{$\begin{array}{c}\begin{array}{c}\text { San } \\
\text { Vicente }\end{array} \\
7 \\
(2.47)\end{array}$} \\
\hline Household & Average (SD) & & & & & & & & \\
\hline Size & Max & 10 & 9 & 7 & 10 & 9 & 9 & 11 & 9 \\
\hline & Min & 2 & 1 & 2 & 3 & 3 & 2 & 1 & 2 \\
\hline \multirow{4}{*}{$\begin{array}{l}\text { Age of head of } \\
\text { the household } \\
\text { (years) }\end{array}$} & Average (SD) & 43 & 45 & 47 & 35 & 41 & 44 & 39 & 44 \\
\hline & & $(10.80)$ & $(11.67)$ & $(10.24)$ & $(4.98)$ & $(11.69)$ & $(9.34)$ & $(8.04)$ & (11.83) \\
\hline & Max & 60 & 57 & 56 & 44 & 64 & 60 & 56 & 60 \\
\hline & Min & 29 & 26 & 34 & 28 & 29 & 27 & 25 & 27 \\
\hline \multirow{4}{*}{$\begin{array}{l}\text { Education of } \\
\text { head of the } \\
\text { household }(\%)\end{array}$} & Higher education & 8.57 & 0.00 & 0.00 & 8.33 & 0.00 & 3.23 & 0.00 & 8.33 \\
\hline & High school & 48.57 & 60.00 & 0.00 & 16.67 & 35.71 & 32.26 & 60.00 & 25.00 \\
\hline & To middle school & 17.14 & 0.00 & 100.00 & 50.00 & 42.86 & 29.03 & 40.00 & 50.00 \\
\hline & None & 25.71 & 40.00 & 0.00 & 25.00 & 21.43 & 35.48 & 0.00 & 16.67 \\
\hline Literate? & $\%$ (Yes) & 83 & 90 & 100 & 92 & 93 & 77 & 87 & 83 \\
\hline $\begin{array}{l}\text { Existing } \\
\text { species in the } \\
\text { chakras }\end{array}$ & \multicolumn{9}{|c|}{$\begin{array}{l}\text { Cacao (Theobroma bicolor L.), coffee (Caffea sp.), manioc (Manihot esculenta), plantain banana (Musa paradisiaca), } \\
\text { corn (Zea mays), sugar cane (Saccharum officinarum), annatto (Bixa orellana) and pacay (Inga spp.) }\end{array}$} \\
\hline Animals & \multicolumn{9}{|c|}{ Poultry (laying hens, broilers, ducks) } \\
\hline
\end{tabular}

Sector, Community set; SD, Standard deviation; Max, Maximum; Min, Minimum. 


\subsection{Cluster Analysis and Sustainability Indicators}

\subsubsection{Values in Sector A}

Using the indicators resulting from the evaluation of the sustainability of traditional agroforestry systems (chakra) in sector A using hierarchical cluster analysis, three groups were obtained in a dendrogram (Figure 4) with a Euclidean distance (measurement of association): in groups 1 and 2, we gathered 24 chakras; in group 3 , there were 13 chakras.

In the three groups (Table 4), the indicators identified by level of importance (highest to lowest average scores) were: energy and climate (86.82), working conditions (77.89), water use (74.97), and land use (72.62). The quality of life indicator in groups 2 and 3 had a difference of 17.77. The indicators that scored medium performance were biodiversity and use of materials and environmental protection, with average values of 64.52 and 41.94, respectively. In groups 1 and 3, the indicator animal production had a difference of 3.56 and the quality of life in group 1 has a score of 64.25. The lowest performing indicators were: economic viability and administration, presenting averages of 29.19 and 23.66, respectively; and in group 2, the indicator animal production was 30.38 .

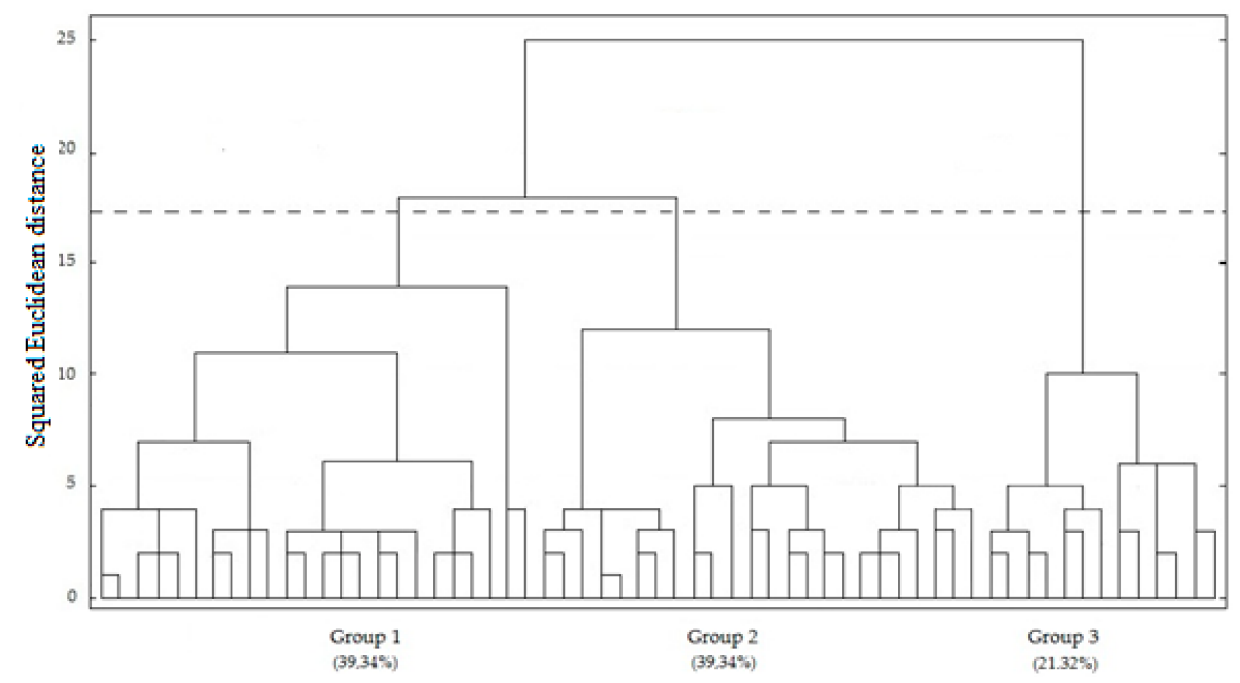

Figure 4. Dendrogram using a Ward linkage to establish three groups within the Kichwa communities in sector A (Pompeii, Indillama, Santa Elena, and Itaya) in the northern Yasuní Biosphere Reserve (YBR) of the Ecuadorian Amazon (percentage of chakras in each group).

Table 4. Means and standard deviation of sustainability indicators among clusters (groups) of the chakra systems in sector A in the north of the Yasuní Biosphere Reserve in the Ecuadorian Amazon region.

\begin{tabular}{|c|c|c|c|c|c|c|c|}
\hline \multirow{3}{*}{ Indicators } & \multicolumn{6}{|c|}{ Groups** } & \multirow{3}{*}{$\begin{array}{c}\text { Overall Mean } \\
\text { of Sector A }\end{array}$} \\
\hline & \multicolumn{2}{|c|}{ Group $1(24)$} & \multicolumn{2}{|c|}{ Group $2(24)$} & \multicolumn{2}{|c|}{ Group 3 (13) } & \\
\hline & Mean & SD & Mean & SD & Mean & SD & \\
\hline Land use & 70.83 & 4.07 & 73.50 & 5.48 & 73.54 & 3.04 & 72.62 \\
\hline Animal production & 38.25 & 4.41 & 30.38 & 10.38 & 34.69 & 7.27 & 34.44 \\
\hline Use of materials and environmental protection & 36.54 & 7.60 & 46.58 & 7.15 & 42.69 & 9.68 & 41.94 \\
\hline Water use & 75.08 & 3.83 & 74.67 & 4.24 & 75.15 & 4.22 & 74.97 \\
\hline Energy and climate & 87.00 & 0.00 & 86.46 & 2.65 & 87.00 & 0.00 & 86.82 \\
\hline Biodiversity & 65.54 & 5.45 & 64.71 & 4.27 & 63.31 & 4.44 & 64.52 \\
\hline Working conditions & 76.83 & 4.95 & 80.46 & 2.06 & 76.38 & 5.41 & 77.89 \\
\hline Quality of life & 64.25 & 6.35 & 69.08 & 5.45 & 86.85 & 4.88 & 73.39 \\
\hline Economic viability & 29.79 & 6.95 & 28.71 & 3.70 & 29.08 & 6.74 & 29.19 \\
\hline Administration of the chakra & 24.33 & 2.76 & 22.79 & 2.48 & 23.85 & 2.88 & 23.66 \\
\hline Global indicator of sustainability & 56.84 & & 57.73 & & 59.25 & & 57.94 \\
\hline
\end{tabular}

** There were no significant statistical differences between the evaluated groups. 
The overall sustainability indicator in the three groups was medium. The best score was obtained in group 3, whose differences between group 2 and group 1 were 1.52 and 2.41, respectively. Sustainability dynamics by group and color were blue for group 1, orange for group 2, and red for group 3 (Figure 5).

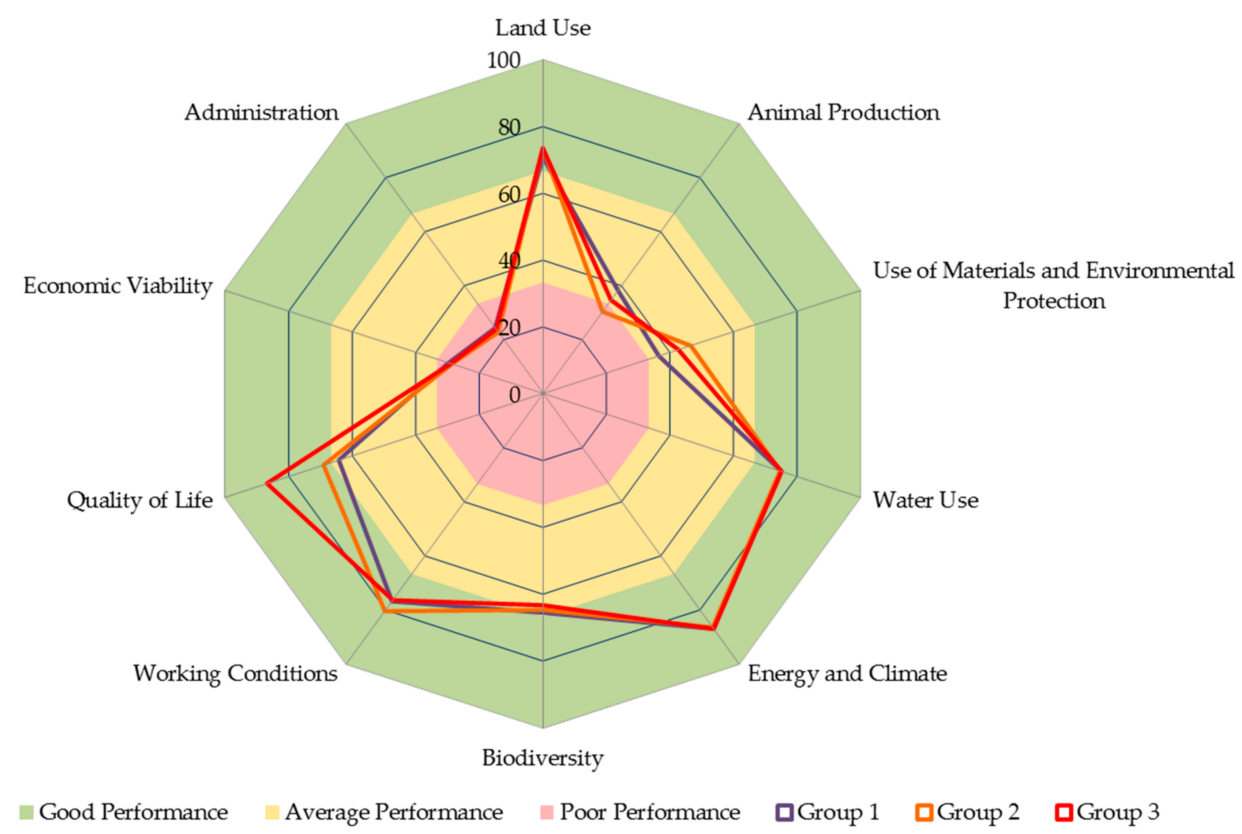

Figure 5. Degree of sustainability of the Kichwa indigenous communities for groups 1, 2, and 3 of sector A in the north of the Yasuní Biosphere Reserve in the Ecuadorian Amazon region.

\subsubsection{Values in Sector B}

Similarly, the results of the chakras in sector B were obtained and grouped into a dendrogram (Figure 6) with a Euclidean distance (measurement of association) of 14. Three groups were obtained: in group 1, there were 21 chakras; group 2 had 24; and group 3 had 27.

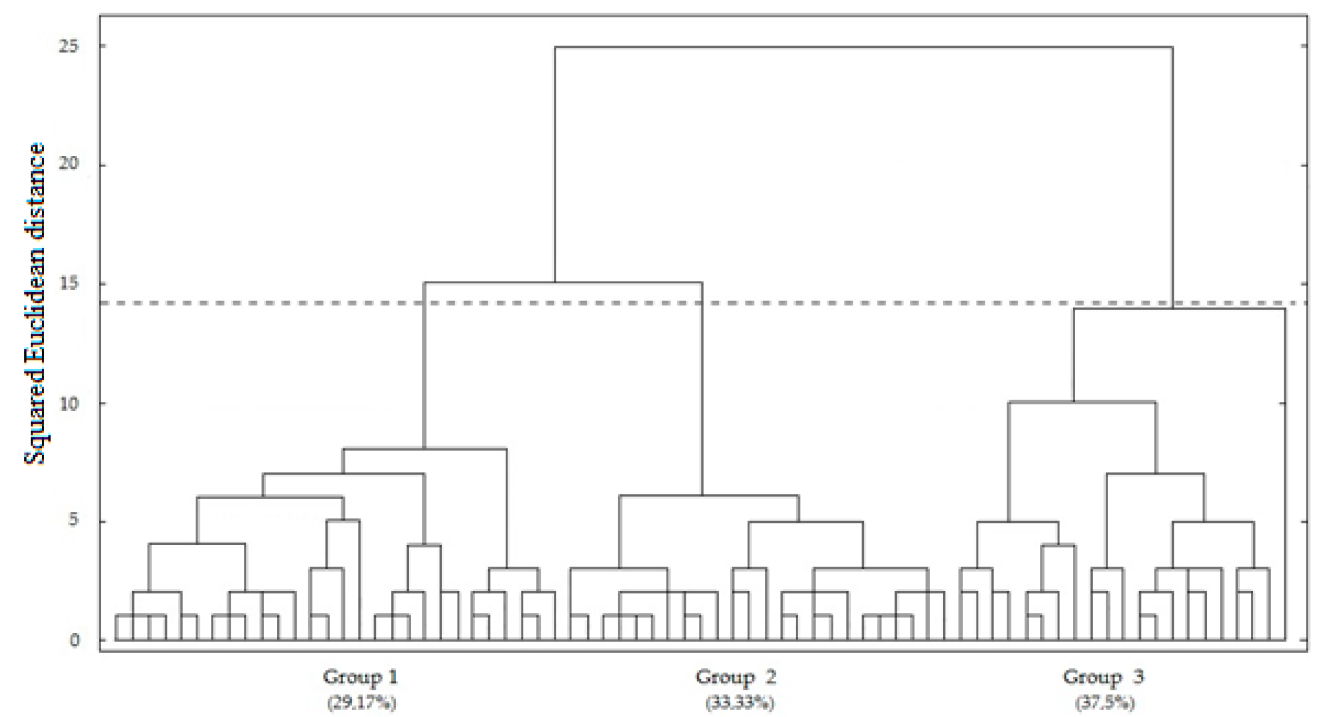

Figure 6. Dendrogram using Ward's linkage: Communities in sector B (Samona Yuturi, Chiru Isla, Sinchi Chicta Cari, and San Vicente) in the north of the Yasuní Biosphere Reserve in the Ecuadorian Amazon region (percentage of chakras in each group).

The indicators with good performance (Table 5) from highest to lowest average scores in the three groups were: energy and climate (92.39), water use (80.18), working conditions (75.57), and land use 
(67.23). The Bbodiversity indicator in group 1 had 2.68 points more than in group 2; the quality of life indicator in group 3 had 12.52 and 7.9 points more than groups 1 and 2, respectively. The indicators with medium performance were: Animal production, which had an average of 37.90 in the three groups; use of materials and environmental protection in group 1 was 15.78 and 14.17 points higher than groups 2 and 3, respectively. In group 3, biodiversity had 4.53 and 1.85 fewer points than groups 1 and 2, respectively. The quality of life indicator in group 2 was 4.62 points higher than group 1 , and in management, group 3 had the best score with a difference of 8.48 and 6.12 from groups 1 and 2, respectively. The lowest performing indicators were: economic viability in all three groups, having an average of 29.81. Group 1 had the best score with 5.05 and 2.82 more points than groups 2 and 3 , respectively. Materials use and environmental protection was 1.61 points higher in group 3 than in group 2, and management was higher in group 2 than group 1 by 2.36 points.

Table 5. Means and SDs of sustainability indicators among clusters (groups) of the chakra systems in sector B in the north of the Yasuní Biosphere Reserve in the Ecuadorian Amazon region.

\begin{tabular}{|c|c|c|c|c|c|c|c|}
\hline \multirow{3}{*}{ Indicators } & \multicolumn{6}{|c|}{ Groups ** } & \multirow{3}{*}{$\begin{array}{c}\text { Overall Mean } \\
\text { of Sector B }\end{array}$} \\
\hline & \multicolumn{2}{|c|}{ Group $1(21)$} & \multicolumn{2}{|c|}{ Group $2(24)$} & \multicolumn{2}{|c|}{ Group 3 (27) } & \\
\hline & Mean & SD & Mean & SD & Mean & SD & \\
\hline Land use & 67.38 & 3.22 & 67.13 & 2.11 & 67.18 & 4.99 & 67.23 \\
\hline Animal production & 41.00 & 9.23 & 38.58 & 3.11 & 34.11 & 5.93 & 37.90 \\
\hline Use of materials and environmental protection & 43.24 & 10.47 & 27.46 & 3.15 & 29.07 & 5.74 & 33.26 \\
\hline Water use & 80.29 & 3.89 & 80.83 & 2.55 & 79.43 & 2.6 & 80.18 \\
\hline Energy and climate & 92.14 & 2.15 & 92.04 & 3.00 & 93.00 & 0.00 & 92.39 \\
\hline Biodiversity & 70.10 & 5.58 & 67.42 & 3.48 & 65.57 & 3.49 & 67.70 \\
\hline Working conditions & 74.95 & 3.07 & 72.58 & 5.04 & 79.18 & 2.68 & 75.57 \\
\hline Quality of life & 61.05 & 14.68 & 65.67 & 3.42 & 73.57 & 6.47 & 66.76 \\
\hline Economic viability & 32.43 & 8.58 & 27.38 & 3.55 & 29.61 & 3.65 & 29.81 \\
\hline Administration of the chakra & 27.52 & 7.39 & 29.88 & 5.07 & 36.00 & 5.93 & 31.13 \\
\hline Global indicator of sustainability & 59.01 & & 56.90 & & 58.67 & & 58.19 \\
\hline
\end{tabular}

** There were no significant statistical differences between the evaluated groups.

The overall sustainability indicator in all three groups was medium, with the best score being in group 1, which was 2.11 and 0.34 higher than in groups 2 and 3, respectively. The dynamics of the degree of sustainability by groups and color were blue for group 1 , orange for group 2 , and red for group 3 (Figure 7).

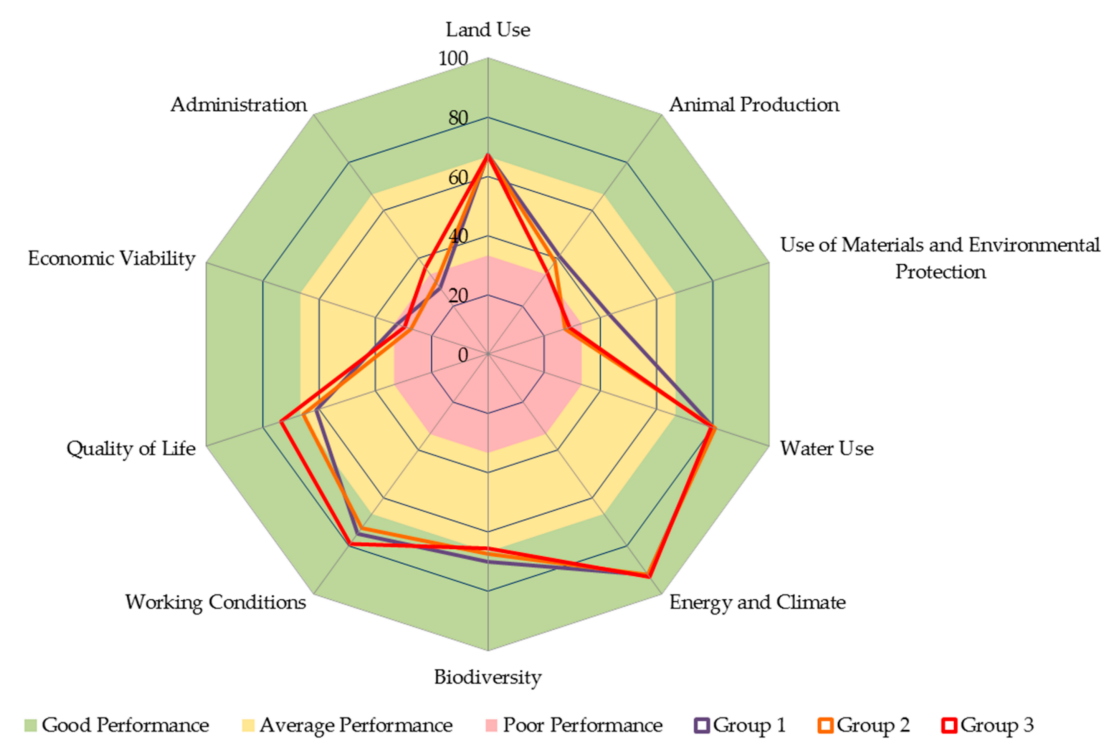

Figure 7. Degree of sustainability of the Kichwa indigenous communities for groups 1, 2, and 3 of sector B in the north of the Yasuní Biosphere Reserve in the Ecuadorian Amazon region. 


\section{Discussion}

The two aspects that were studied in this research: (1) the population and agricultural dynamics of the Kichwa population, and (2) the indicators of the evaluation of sustainability in the chakras. The maximum size per Kichwa household was 11 people, and of the heads of households, approximately $21 \%$ had no educational. In terms of sustainability, the chakras did not present significant differences, although only 5 of the 10 analyzed indicators showed good performance, and the economic viability and administration indicators were performing poorly.

\subsection{Socio-Demographic and Agricultural Characterization of the Indigenous Kichwa Population}

Currently, defining who counts as a resident of the communities is difficult because many young people often come into and out of the study area, mainly for education and marriage, which is a typical dynamic of indigenous people in the north of the Ecuadorian Amazon [107]. Therefore, we describe the socio-demographic characteristics of the population interviewed in 2018.

Figure 3 shows that there was little difference (3.03\%) in the population proportion of Kichwa men and women (48.48 and $51.51 \%$, respectively). The proportions of youth and adults were $40.63 \%$ and $59.37 \%$, respectively. The ratio of Kichwa children to women $(0.45 \%)$ was much lower than that of Waorani $(0.91 \%)$ and Shuar $(0.98 \%)$ indigenous women [108]. The youth dependency population was $28 \%$ higher than the working age population, which corroborates the high birth rates in indigenous populations [109]. In the 40-64-year age range (birth year from 1978 to 1958), only 17.1\% of the indigenous Kichwa population is of working age; this value may be influenced by migratory processes [107].

The maximum number of people per household (Table 3) ranged between 7 and 11 members including two parents, which is probably related to higher fertility rates [80] driven by the lack of access to family planning and reproductive health services among indigenous peoples in the Amazon [110-112]. Although it has been debated whether the high fertility among indigenous populations is linked to pronatalism and the desire to repopulate indigenous lands [113-115], the rapid changes in the northern Amazon region have had profound impacts on the demographic dynamics of local indigenous people, including changing patterns of settlement and livelihood strategies, and increasing interactions with markets [116-122].

The heads of household did not complete higher education, despite starting their higher studies; $35.34 \%$ (sector A) and $56.39 \%$ (sector B) of the heads of household had completed secondary and basic education, respectively. In the Northern Amazon region of Ecuador, the most educated households are likely to have higher non-agricultural incomes than the least educated households in mostly migrant settler populations $[120,121]$. Participation in non-agricultural employment may be driven by push factors such as declining soil fertility, low yields, small production areas, and isolation from markets, which negatively affect farm income [122,123].

\subsection{Evaluation of Sustainability Based on the RISE Methodology}

According to the ANOVA using the results of the RISE, we found no significant differences between groups and sectors evaluated in the northeast of the YBR. The RISE tool, compared with other frameworks for the evaluation of sustainability, produced the best results in some categories such as scientific soundness, usefulness, adaptability, etc. [52], but it lacks a cultural approach based on the location, which can be detrimental to the communities under evaluation [123,124]. Biocultural approaches are those that start explicitly with and are based on cultural perspectives on the basis of the place and the embodied values, knowledge and needs, and recognize the feedback between the ecological state and human well-being $[125,126]$. These approaches, in combination with the guidelines of the different sustainability assessment tools, can be used to develop indicators to more accurately depict reality [127]. The exchange between in situ and ex situ actors facilitates the identification 
of crucial problems and solutions that are currently lacking in many regional and international sustainability tools $[126,128,129]$.

The indigenous populations in this zone are associated with sustainable agricultural practices [130] that have little environmental impact and are compatible with resource conservation $[47,131]$. This is corroborated by the excellent scores for land use and water use within the Kichwa chakra dynamics, similar to the Shumahuani people (Peruvian Amazon), who keep most of their land in the forest and use sustainable management practices in contrast to the migrant settlers who cut down the forest to establish pastures [132]. In the Ecuadorian Amazon Region, most soils are not suitable for agriculture $[133,134]$ and the settlers tended to compensate for the low fertility by clearing more land for cultivation. As a consequence, deforestation rates in the Ecuadorian Amazon Region are considered one of the highest in the world [135].

Chakras are complex systems that adapt to and resist the effects of climate change and development [104,105], have high structural complexity [136,137], and present high levels of carbon sequestration [28] and tree diversity [30] compared with other forms of land use. Chakras also allow for the sustainable use of forests by combining the cultivation of fine and aromatic Ecuadorian cocoa, controlled wood extraction, production of basic food items, and the conservation of medicinal plants. In Amazonian communities, chakras contribute to food security as well as to the well-being and conservation of the region's high biodiversity [28]. The adequate management of the chakras increases their potential to recover part of the carbon released into the atmosphere due to deforestation [138]. This is contrary to the circumstances in the evaluated chakras, since the indicator for use of materials and environmental protection had critical and average scores, influenced by the poor management of the chakra: (1) nitrogen and phosphorus balance, (2) ammonia emissions, and (3) waste management $[63,100,101]$, as the sustainability objective of the indicator is the use of natural cycles [97]. Inadequate waste management can endanger human, animal, and environmental health. Inherited pollution from oil activity can also harm future generations and, therefore, violates the principle of sustainability [139]., which is influenced by the non-agricultural income received from providing unskilled labor services to oil companies, as well as external assistance from the government and international non-governmental organizations (NGOs). All this results in the chakras not being adequately cared for [140].

The Kichwa people obtain their livelihood mainly from subsistence agriculture, collection of forestry products, hunting, and fishing [141,142], all of which are related to the diversity of species in the chakras, but it had a critical score within the biodiversity indicator [56,57]. Scientific evidence shows that some Kichwa have adopted migrant-settler-style agricultural systems and engage in commercial agriculture, such as cattle ranching, logging, and off-farm wage employment in areas near roads and urban centers $[23-25,143,144]$. The integration of Kichwas into the market economy has received attention in the literature because of its implications for both human well-being and ecological viability. Animal production has often been driven by oil companies and embodied in livestock breeding projects [145], which justifies the low values in the animal production indicator, since it is not part of the socio-productive dynamics of the Kichwa people.

In terms of quality of life, the studied Kichwa population received outstanding and medium scores; the best scores were expressed in the parameters of social relations and personal freedom and values; the worst score was in the parameter of health [95-97]. Notably, the studied Kichwa population lives in an area overlapped by oil blocks, and in the period from 2001 to 2011, 464 accidental oil spills were registered [146], resulting in a high level of environmental contamination [147]. In 2018, the presence of 1-hydroxypyrene (1-OHP) and creatinine (chemical products from oil activities) was confirmed in the urine of Kichwa indigenous people (inhabitants of the banks of the Napo River) due to the consumption of contaminated food. In addition, the toxicity of drinking water has been revealed, which has caused health problems ranging from dizziness to cancer [148-150]. Within the excellent scores of the working conditions indicator in the chakras, an average score was received for the staff management parameter. An important variable of this parameter is child and adolescent work in the 
RISE methodology, as established by the Universal Declaration of Human Rights [151], understanding that the RISE guidelines do not consider underage work. This stands in opposition to the Kichwan cultural dynamics in the management of the chakras since, from a social perspective, it is the result of a set of values, deeply ingrained in the Kichwa cosmovision [51], where ancestral knowledge is transmitted from generation to generation through harmonious relationships, based on solidarity and reciprocity [152]. The contributions of indigenous and local knowledge (ILK) to research is increasingly considered in the science of sustainability [153,154]. ILK is defined as a cumulative body of knowledge, practices, and beliefs that have evolved through processes of adaptation and are transmitted from generation to generation by cultural transmission, through the relationship of living beings (including humans) with each other and with their environment [155-157]. The precarious economic viability and management of the chakras, which have both been obtained, make it more likely that timber will be sold illegally and that income will be earned outside the farm [158]. Given the dynamic evidence for each group in each sector, there is a need to integrate and promote new economic models and reconfigurations of the territory, which may involve changes in governance systems that generate an integration of essential indigenous rules that positively influence chakra management [159].

The sustainability assessments in the Kichwa chakras showed certain problems related to the dimensions of the RISE methodology, which must be resolved to improve the level of sustainability. There are priorities (high, medium, and low) for the management of the territory that could be adopted by local political agents to support the Kichwa populations and to strengthen the studied indicators (Table 6).

Table 6. Recommendations to strengthen the indicators resulting from the evaluation of sustainability.

\begin{tabular}{|c|c|c|c|}
\hline Indicators & Recommendation & Examples & Priority \\
\hline Land use & $\begin{array}{l}\text { 1. Increase species biodiversity in the chakras. } \\
\text { 2. Incorporate species to increase nitrogen fixation and } \\
\text { prevent soil erosion. }\end{array}$ & {$[160,161]$} & Medium \\
\hline Animal production & 1. Seek advice on the proper handling of poultry and animals. & [162] & High \\
\hline $\begin{array}{l}\text { Use of materials and } \\
\text { environmental protection }\end{array}$ & $\begin{array}{l}\text { 1. Improve weed management. } \\
\text { 2. Use more organic fertilizers to improve the balance } \\
\text { of nutrients. } \\
\text { 3. Use cover crops. } \\
\text { 4. Use certified seeds. }\end{array}$ & [163-165] & Medium \\
\hline Water use & $\begin{array}{l}\text { 1. Incorporate technologies to save water and make an } \\
\text { inventory of good practices. }\end{array}$ & [166] & Low \\
\hline Energy and climate & $\begin{array}{l}\text { 1. Strengthen the governance system of natural resources. } \\
\text { 2. Incorporate solar panels for electrical use and a solar } \\
\text { water heating. } \\
\text { 3. Evaluate the perception of the changing climate at the } \\
\text { rural, academic, and local public policy levels. }\end{array}$ & {$[167-170]$} & Low \\
\hline Biodiversity & $\begin{array}{l}\text { 1. Disseminate knowledge about ecological infrastructure. } \\
\text { 2. Tools for capacity building. } \\
\text { 3. Promote the use of local varieties. }\end{array}$ & {$[171-174]$} & Medium \\
\hline Working conditions & 1. Training to maintain or improve working conditions. & [175] & Low \\
\hline Quality of life & $\begin{array}{l}\text { 1. Improve education and training levels. } \\
\text { 2. Promote talks and courses to improve health conditions } \\
\text { in the family. } \\
\text { 3. Promote sustainable behavior workshop based on } \\
\text { scientific evidence. }\end{array}$ & {$[176-178]$} & Medium \\
\hline
\end{tabular}


Table 6. Cont.

\begin{tabular}{|c|c|c|c|}
\hline Indicators & Recommendation & Examples & Priority \\
\hline Economic viability & $\begin{array}{l}\text { 1. Develop revenues from projects for reducing emissions } \\
\text { from deforestation and degradation (REDD }+ \text { ). } \\
\text { 2. Generate opportunities to create marketing chains } \\
\text { 3. Promote the diversification of economic income. }\end{array}$ & {$[143,177,179]$} & High \\
\hline $\begin{array}{l}\text { Administration of the } \\
\text { traditional agroforestry } \\
\text { system (Chakra) }\end{array}$ & 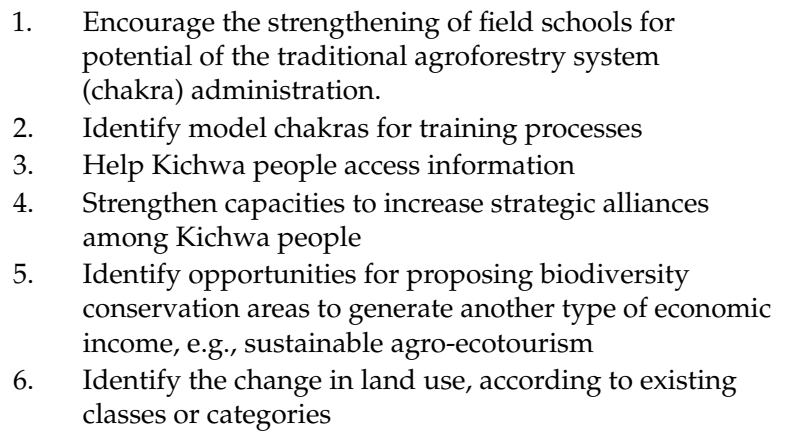 & [180-185] & High \\
\hline
\end{tabular}

\section{Conclusions}

The average degree of sustainability of the studied Kichwa chakras had a medium score for both sectors. In general terms, we argue that the Kichwa chakras located along the banks of the Napo River have certain weaknesses for the following indicators based on the RISE guidelines: use of materials and environmental protection, animal production, economic viability, and administration of the traditional chakra system. Given the very low values for the economic indicators and for administration in the traditional agroforestry system (chakras), losses are generated compared to the neocolonial models belonging to the migrant settlers and potential structural changes in the landscape agroforestry. However, we also identified strengths in the following indicators: energy and climate, water use, working conditions, biodiversity, land use, and quality of life.

The holistic evaluation of the chakras' sustainability using the RISE tool provides a system of early warning and can be used to help identify potential measures to improve the situation of the indigenous Kichwa people in the Yasuní Biosphere Reserve. In addition, the results provide a scientific basis for the people in charge of formulating public policies to improve strategies for the rescue and management of the chakras. Consequently, this would improve quality of life, strengthen food security and sovereignty, bolster self-employment, and increase the production of sustainable products among Kichwa populations in the Ecuadorian Amazon region.

Although the RISE methodology was not designed to be used as an instrument of certification, it could offer additional value for some process of certification, for example, organic certification of the chakras, conservation of the biodiversity of species in productive spaces, and so on.

Author Contributions: M.H.-R., J.C., and N.R. conducted the field work in this study. M.H.-R., B.T., J.C., N.R., M.L. and C.G.H.D.-A., analyzed the data, compiled the literature, prepared the text, and approved the final manuscript. All authors have read and agreed to the published version of the manuscript.

Funding: This research received no external funding.

Acknowledgments: We would like to thank the German Development Cooperation Agency (GIZ-Ecuador) for their collaboration in the field logistics. We are also grateful to the Yasuní National Park rangers for their help during the data collection, as well as the 133 Kichwa households who shared valuable information with us during the visits about their socio-demographic characteristics and chakra production systems.

Conflicts of Interest: The authors declare no conflict of interest. 


\section{References}

1. Burger, J. Report from the Frontier: The State of the World's Indigenous Peoples; Cultural Survival Inc.: London, UK, 1987.

2. Toledo, V.M. Indigenous Peoples and Biodiversity. Encycl. Biodivers. 2013, 3, 269-278. [CrossRef]

3. Persoon, G.A.; Minter, T.; Slee, B.; van der Hammen, C. The Position of Indigenous Peoples in the Management of Tropical Forests; Tropenbos: Wageningen, The Netherlands, 2004.

4. Mittermeier, R.A. Biodiversity. In Primate Diversity and the Tropical Forest. Case Studies from Brazil and Madagascar and the Importance of the Megadiversity Countries; Wilson, E.O., Peter, F.M., Eds.; National Academy Press: Washington, DC, USA, 1998; pp. 145-154.

5. Myers, N. Threatened biotas:"Hot spots" in tropical forests. Environmentalist 1988, 8, 187-208. [CrossRef] [PubMed]

6. Dangles, O.; Nowicki, F. Biota Maxima: Ecuador Biodiverso; Pontificia Universidad Catolica del Ecuador (PUCE): Quito, Ecuador; Institut de Recherche pour le Developpment: Quito, Ecuador, 2010.

7. Steege, H.T.; Pitman, N.C.A.; Sabatier, D.; Castellanos, H.; van der Hout, P.; Daly, D.C.; Silveira, M.; Phillips, O.; Vasquez, R.; Van Andel, T.; et al. A spatial model of tree $\alpha$-diversity and $\beta$-density for the Amazon Region. Biodivers. Conserv. 2003, 12, 2255-2276. [CrossRef]

8. Erwin, T.L.; Pimienta, M.C.; Murillo, O.E.; Aschero, V. Mapping patterns of $\beta$-diversity for beetles across the western Amazon Basin: A preliminary case for improving conservation strategies. Proc. Calif. Acad. Sci. 2004, 56, 72-85.

9. Ceballos, G.; Ehrlich, P.R. Global mammal distributions, biodiversity hotspots, and conservation. Proc. Natl. Acad. Sci. USA 2006, 103, 19374-19379. [CrossRef]

10. Killeen, T.J.; Douglas, M.; Consiglio, T.; Jørgensen, P.M.; Meika, J. Dry spots and wet spots in the Andean hotspot. J. Biogeogr. 2007, 34, 1357-1373. [CrossRef]

11. Napolitano, D.A.; Ryan, A.S. The dilemma of contact: Voluntary isolation and the impacts of gas exploitation on health and rights in the Kugapakori Nahua Reserve, Peruvian Amazon. Environ. Res. Lett. 2007, 2, 1-12. [CrossRef]

12. Gamboa Balbín, C.; Santillán Bartra, A. Régimen Especial Transectorial de Protección a Favor de Pueblos Indígenas en Aislamiento y en Contacto Inicial; Bellido Ediciones EIRL: Lima, Peru, 2006.

13. Heredia Rengifo, M.G.; Hernández Díaz-Ambrona, C.G. Comportamiento demográfico: Dinámico-Probabilístico de los pueblos indígenas en aislamiento de la amazonía ecuatoriana. Revista Científica Axioma 2019, 20, 25-34.

14. Inec. Ecuadorencifras.Gob.Ec. (En Línea). 2010. Available online: http://www.ecuadorencifras.gob.ec/ estadisticas/ (accessed on 20 March 2020).

15. Torres, B.; Günter, S.; Acevedo-Cabra, R.; Knoke, T. Livelihood strategies, ethnicity and rural income: The case of migrant settlers and indigenous populations in the Ecuadorian Amazon. For. Policy Econ. 2018, 86, 22-34. [CrossRef]

16. Uzendoski, M.; Whitten, N.E., Jr. From “Acculturated Indians" to "Dynamic Amazonian Quichua-Speaking Peoples. Tipití J. Soc. Anthropol. Lowl. South Am. 2014, 12, 1-13.

17. Muratorio, B. Rucuyaya Alonso y la Historia Social y Económica del Alto Napo; Docutech: Quito, Ecuador, 1998; pp. 1850-1950.

18. Finer, M.; Jenkins, C.N.; Pimm, S.L.; Keane, B.; Ross, C. Oil and Gas Projects in the Western Amazon: Threats to Wilderness, Biodiversity, and Indigenous Peoples. PLoS ONE 2008, 3, e2932. [CrossRef] [PubMed]

19. Juteau-Martineau, G.; Becerra, S.; Maurice, L. Ambiente, petróleo y vulnerabilidad política en el oriente ecuatoriano:¿ hacia nuevas formas de gobernanza energética? Am. Lat. Hoy 2014, 67, 119-137. [CrossRef]

20. Bilsborrow, R.E.; Barbieri, A.F.; Pan, W. Changes in population and land use over time in the Ecuadorian Amazon. Acta Amazonica 2004, 34, 635-647. [CrossRef]

21. Lu, F.; Bilsborrow, R.E. A Cross-Cultural Analysis of Human Impacts on the Rainforest Environment in Ecuador. In Human Population; Springer: Berlin, Germany, 2011; pp. 127-151.

22. Vasco, C.; Bilsborrow, R.; Torres, B.; Griess, V. Agricultural land use among mestizo colonist and indigenous populations: Contrasting patterns in the Amazon. PLoS ONE 2018, 137, e0199518. [CrossRef] 
23. Torres, B.; Vasco, C.; Günter, S.; Knoke, T. Determinants of agricultural diversification in a hotspot area: Evidence from colonist and indigenous communities in the Sumaco Biosphere Reserve, Ecuadorian Amazon. Sustainability 2018, 10, 1432. [CrossRef]

24. Gray, C.L.; Bilsborrow, R.E.; Bremner, J.L.; Flora, L. Indigenous Land Use in the Ecuadorian Amazon: A Cross-cultural and Multilevel Analysis. Hum. Ecol. 2008, 36, 97-109. [CrossRef]

25. Lu, H.F. Integration into the market among indigenous peoples: A cross-cultural perspective from the Ecuadorian Amazon. Curr. Anthropol. 2007, 48, 593-602. [CrossRef]

26. Ferrer Velasco, R.; Köthke, M.; Lippe, M.; Günter, S. Scale and context dependency of deforestation drivers: Insights from spatial econometrics in the tropics. PLoS ONE 2020, 151, e0226830. [CrossRef]

27. Barlow, J.; Lennox, G.D.; Ferreira, J.; Berenguer, E.; Lees, A.C.; Mac Nally, R.; Thomson, J.R.; de Barros Ferraz, S.F.; Louzada, J.; Oliveira, V.H.F.R.; et al. Anthropogenic disturbance in tropical forests can double biodiversity loss from deforestation. Nature 2016, 535, 144. [CrossRef]

28. Torres, B.; Maza, O.J.; Aguirre, P.; Hinojosa, L.; Günter, S. The Contribution of Traditional Agroforestry to Climate Change Adaptation in the Ecuadorian Amazon: The Chakra System. In Handbook of Climate Change Adaptation; Springer: Berlin, Germany, 2015; pp. 1973-1994.

29. Coq-Huelva, D.; Higuchi, A.; Alfalla-Luque, R.; Burgos-Morán, R.; Arias-Gutiérrez, R. Co-evolution and bio-social construction: The Kichwa agroforestry systems (chakras) in the Ecuadorian Amazonia. Sustainability 2017, 9, 1920. [CrossRef]

30. Vera, V.R.R.; Cota-Sánchez, J.H.; Grijalva Olmedo, J.E. Biodiversity, dynamics, and impact of chakras on the Ecuadorian Amazon. J. Plant Ecol. 2019, 12, 34-44. [CrossRef]

31. Irvine, D. Indigenous federations and the market: The Runa of Napo, Ecuador. In Indigenous People and Conservation Organizations Experiences in Collaborations; Weber, R., Butler, J., Larson, P., Eds.; World Wildlife Fund: Washington, DC, USA, 2000; pp. 21-46.

32. Lu, F.; Bilsborrow, R.E.; Oña, A. Demography, Household Economics, and Land and Resource Use of Five Indigenous Populations in the Northern Ecuadorian Amazon: A Summary of Ethnographic Research; Occasional Paper; Carolina Population Centre, University of North Carolina: Chapel Hill, NC, USA, 2004.

33. Whitten, N.E.; Whitten, D.S. Puyo Runa: Imagery and Power in Modern Amazonia; University of Illinois Press: Champaign, IL, USA, 2008.

34. Coq-Huelva, D.; Torres-Navarrete, B.; Bueno-Suárez, C. Indigenous worldviews and Western conventions: Sumak Kawsay and cocoa production in Ecuadorian Amazonia. Agric. Hum. Values 2018, 35, 163-179. [CrossRef]

35. GESOREN-GIZ. Fomento de la Cadena de Valor de Cacao en Organizaciones de Pequeños Productores de Esmeraldas y Napo; Análisis de Impactos del Programa, Fascículo 5; GIZ: Quito, Ecuador, 2011; p. 93.

36. Lehmann, S.; Rodríguez, J. La Chakra Kichwa: Criterios para la Conservación y Fomento de un Sistema de Producción Sostenible en la Asociación Kallari y sus Organizaciones Socias; Serie de Sistematización 7, 201; GIZ: Quito, Ecuador, 2013; pp. 20-31.

37. Reeve, M.E. Los Quichua del Curaray: El Proceso de Formación de la Identidad; Editorial Abya Yala: Quito, Ecuador, 2002; ISBN 9978-22-020-8.

38. Santafe-Troncoso, V.; Loring, P.A. Indigenous food sovereignty and tourism: The Chakra Route in the Amazon region of Ecuador. J. Sustain. Tour. 2020, 29, 1-20. [CrossRef]

39. Andy, P.; Calapucha, A.; Calapucha, L.; López, H.; Shiguango, K.; Tanguila, A.; Tanguila, A.; Yasacama, C. Sabiduría de la Cultura Kichwa de la Amazonía Ecuatoriana, 1st ed.; Tomo, I., Ed.; Universidad De Cuenca: Cuenca, Ecuador, 2012; ISBN 978-9978-14-000-0.

40. Hingh, S.J.; Haas, W.; Fraňková, E. Conclusions: Promises and Challenges for Sustainable Agri-Food Systems. In Socio-Metabolic Perspectives on the Sustainability of Local Food Systems; Springer: Cham, Germany, 2017; pp. 345-356.

41. Godfray, H.C.J.; Beddington, J.R.; Crute, I.R.; Haddad, L.; Lawrence, D.; Muir, J.F.; Pretty, J.; Robinson, S.; Thomas, S.M.; Toulmin, C. Food Security: The Challenge of Feeding 9 Billion People. Science 2010, 327, 812-818. [CrossRef]

42. Foley, J.A.; Ramankutty, N.; Brauman, K.A.; Cassidy, E.S.; Gerber, J.S.; Johnston, M.; Mueller, N.D.; O'Connell, C.; Ray, D.K.; West, P.C.; et al. Solutions for a cultivated planet. Nature 2011, 478, 337-342. [CrossRef] 
43. Gil, J.D.B.; Reidsma, P.; Giller, K.E.; Todman, L.C.; Whitmore, A.P.; Van Ittersum, M.K. Sustainable development goal 2: Improved targets and indicators for agriculture and food security. Ambio 2019, 48, 685-698. [CrossRef]

44. Pope, J.; Annandale, D.; Morrison-Saunders, A. Conceptualising sustainability assessment. Environ. Impact Assess. Rev. 2004, 24, 595-616. [CrossRef]

45. Purvis, B.; Mao, Y.; Robinson, D. Three pillars of sustainability: In search of conceptual origins. Sustain. Sci. 2019, 14, 681-695. [CrossRef]

46. Valizadeh, N.; Hayati, D. Development and validation of an index to measure agricultural sustainability. J. Clean. Prod. 2021, 280, 123797. [CrossRef]

47. Dufour, D.L. Use of Tropical Rainforests by Native Amazonians. Bioscience 1990, 40, 652-659. [CrossRef]

48. Astier, M.; García-Barrios, L.; Galvan-Miyoshi, Y.; González-Esquivel, C.E.; Masera, O.R. Assessing the Sustainability of Small Farmer Natural Resource Management Systems. A Critical Analysis of the MESMIS Program (1995-2010). Ecol. Soc. 2012, 17. [CrossRef]

49. Ebel, R. Are Small Farms Sustainable by Nature?-Review of an Ongoing Misunderstanding in Agroecology. Challenges Sustain. 2020, 8, 17-29. [CrossRef]

50. Binder, C.R.; Feola, G.; Steinberger, J.K. Considering the normative, systemic and procedural dimensions in indicator-based sustainability assessments in agriculture. Environ. Impact Assess. Rev. 2010, 30, 71-81. [CrossRef]

51. Schader, C.; Grenz, J.; Meier, M.S.; Stolze, M. Scope and precision of sustainability assessment approaches to food systems. Ecol. Soc. 2014, 19. [CrossRef]

52. Talukder, B.; Blay-Palmer, A. Comparison of Methods to Assess Agricultural Sustainability. Sustain. Agricult. Rev. 2017, 47, 149-168. [CrossRef]

53. Marchand, F.; Debruyne, L.; Triste, L.; Gerrard, C.L.; Padel, S.; Lauwers, L. Key characteristics for tool choice in indicator-based sustainability assessment at farm level. Ecol. Soc. 2014, 19. [CrossRef]

54. Halog, A.; Manik, Y. Advancing Integrated Systems Modelling Framework for Life Cycle Sustainability Assessment. Sustainability 2011, 3, 469-499. [CrossRef]

55. Rasmussen, L.V.; Bierbaum, R.; Oldekop, J.A.; Agrawal, A. Bridging the practitioner-researcher divide: Indicators to track environmental, economic, and sociocultural sustainability of agricultural commodity production. Glob. Environ. Chang. 2017, 42, 33-46. [CrossRef]

56. De Olde, E. Sustainable Development of Agriculture: Contribution of Farm-Level Assessment Tools. Ph.D. Thesis, Wageningen University and Research, Wageningen, The Netherlands, 2017.

57. De Olde, E.M.; Oudshoorn, F.W.; Sørensen, C.G.; Bokkers, E.A.M.; De Boer, I.J. Assessing sustainability at farm-level: Lessons learned from a comparison of tools in practice. Ecol. Indic. 2016, 66, 391-404. [CrossRef]

58. Zahm, F.; Viaux, P.; Vilain, L.; Girardin, P.; Mouchet, C. Assessing farm sustainability with the IDEA method-From the concept of agriculture sustainability to case studies on farms. Sustain. Dev. 2008, 16, 271-281. [CrossRef]

59. FAO. Sustainability Assessment of Food and Agriculture Systems SAFA. Guidelines; Version 3.0; Food and Agriculture Organization of the United Nations: Rome, Italy, 2014.

60. Häni, F.; Braga, A.; Stämpfli Keller, T.; Fischer, M.; Porsche, H. RISE, a tool for holistic sustainability assessment at the farm level. Int. Food Agribus. Manage. Rev. 2003, 6, 78-90.

61. Meul, M.; Passel, S.; Nevens, F.; Dessein, J.; Rogge, E.; Mulier, A.; Hauwermeiren, A. MOTIFS: A monitoring tool for integrated farm sustainability. Agron. Sustain. Dev. 2008, 28, 321-332. [CrossRef]

62. Paracchini, M.L.; Bulgheroni, C.; Borreani, G.; Tabacco, E.; Banterle, A.; Bertoni, D.; Rossi, G.; Parolo, G.; Origgi, R.; De Paola, C. A diagnostic system to assess sustainability at a farm level: The SOSTARE model. Agric. Syst. 2015, 133, 35-53. [CrossRef]

63. Jawtusch, J.; Schader, C.; Stolze, M.; Baumgart, L.; Niggli, U. Sustainability Monitoring and Assessment Routine: Results from pilot applications of the FAO SAFA Guidelines. In Proceedings of the Symposium International sur L'Agriculture Biologique Méditerranénne et Les Signes Distinctifs de Qualité liée à l'Origine, Agadir, Morocco, 2-4 December 2013.

64. Röös, E.; Fischer, K.; Tidåker, P.; Källström, H.N. How well is farmers' social situation captured by sustainability assessment tools? A Swedish case study. Int. J. Sustain. Dev. World Ecol. 2019, 26, 268-281. [CrossRef] 
65. Berbeć, A.K.; Feledyn-Szewczyk, B.; Thalmann, C.; Wyss, R.; Grenz, J.; Kopiński, J.; Stalenga, J.; Radzikowski, P. Assessing the Sustainability Performance of Organic and Low-Input Conventional Farms from Eastern Poland with the RISE Indicator System. Sustainability 2018, 10, 1792. [CrossRef]

66. Heredia-R, M.; Bravo, C.; Vargas-B, J. Sostenibilidad y Manejo de Recursos Naturales a Nivel de Finca: Marco de Evaluación RISE; Torres, B., Radice, M., Ochoa-Moreno, S., Cueva, K., Eds.; Universidad Estatal Amazónica: Puyo, Ecuador, 2017; pp. 120-133.

67. De Olde, E.M.; Oudshoorn, F.W.; Bokkers, E.A.M.; Stubsgaard, A.; Sørensen, C.G.; De Boer, I.J.M. Assessing the Sustainability Performance of Organic Farms in Denmark. Sustainability 2016, 8, 957. [CrossRef]

68. Pineau, M.; Ayalneh, W.; Studer, C.; Peden, D. Response-inducing sustainability evaluation (RISE) linking agricultural practices and water productivity. CGIAR Chall. Progr. Water Food 2009, 2, 110-114.

69. Häni, F.; Gerber, T.F.; Stämpfli, A.; Porsche, H.; Thalmann, C.; Studer, C. RISE: A tool for improving sustainability in agriculture: A case study with tea farmers in southern India. In Sustainable Agriculture: From Common Principles to Common Practice; Häni, F.J., Pintér, L., Herren, H.R., Eds.; International Institute of Sustainable Development and Swiss College of Agriculture: Bern, Switzerland, 2007; pp. 121-148.

70. Thalmann, C.; Urutyan, V.; Porsche, H.; Grigoryan, A.; Studer, C. Sustainability of Agricultural Production in Armenia. Interim Report. España. 2007. Available online: http://citeseerx.ist.psu.edu/viewdoc/download? doi=10.1.1.618.809\&rep=rep1\&type=pdf (accessed on 4 April 2007).

71. Häni, F.; Stämpfli, A.; Tello, J.R.; Braga, F. Sustainability Assessment of Six Brazilian Coffee Farms in Bahia and Minas Gerais; Swiss College of Agriculture: Zollikofen, Switzerland; University of Applied Sciences Bern: Bern, Switzerland; University of Guelph: Guelph, ON, Canada, 2005.

72. Le Gal, P.-Y.; Dugué, P.; Faure, G.; Novak, S. How does research address the design of innovative agricultural production systems at the farm level? A review. Agric. Syst. 2011, 104, 714-728. [CrossRef]

73. De Olde, E.M.; Sautier, M.; Whitehead, J. Comprehensiveness or implementation: Challenges in translating farm-level sustainability assessments into action for sustainable development. Ecol. Indic. 2018, 85, 1107-1112. [CrossRef]

74. Van Meensel, J.; Lauwers, L.; Kempen, I.; Dessein, J.; Van Huylenbroeck, G. Effect of a participatory approach on the successful development of agricultural decision support systems: The case of Pigs2win. Decis. Support Syst. 2012, 54, 164-172. [CrossRef]

75. Villaverde, X.; Ormaza, F.; Marcial, V.; Jorgenson, J. Parque Nacional Yasuní: Historia, Problema y Perspectivas; WCS-Programa Ecuador: Quito, Ecuador, 2005.

76. Uzendoski, M. The Napo Runa of Amazonian Ecuador; University of Illinois Press: Champaign, IL, USA, 2005; Volume 57.

77. Bass, M.S.; Finer, M.; Jenkins, C.N.; Kreft, H.; Cisneros-Heredia, D.F.; McCracken, S.F.; Pitman, N.C.A.; English, P.H.; Swing, K.; Villa, G.; et al. Global Conservation Significance of Ecuador's Yasuní National Park. PLOS ONE 2010, 5, e8767. [CrossRef] [PubMed]

78. Finer, M.; Babbitt, B.; Novoa, S.; Ferrarese, F.; Pappalardo, S.E.; De Marchi, M.; Saucedo, M.; Kumar, A. Future of oil and gas development in the western Amazon. Environ. Res. Lett. 2015, 10, 024003. [CrossRef]

79. Mittermeier, R.A.; Mittermeier, C.; Pil, P.R. Megadiversity: Naciones Biológicamente más ricas de la Tierra; Cemex: Ciudad de México, Mexico, 1997.

80. Myers, N.; Mittermeier, R.A.; Mittermeier, C.G.; Da Fonseca, G.A.B.; Kent, J. Biodiversity hotspots for conservation priorities. Nature 2000, 403, 853-858. [CrossRef] [PubMed]

81. UNESCO. MAB Directorio de Reservas de Biosfera. 1989. Available online: http://www.unesco.org/mabdb/ $\mathrm{br} / \mathrm{brdir} /$ directory/biores.asp? mode=gen\&code=ecu+02 (accessed on 29 November 2019).

82. Guevara, J.; Pitman, N.; Mogollón, H.; Cerón, C.; Palacios, W. Ministerio del Ambiente del Ecuador 2012. Sistema de Clasificación de los Ecosistemas del Ecuador Continental; Ministerio del Ambiente del Ecuador: Cuenca, Ecuador, 2013; pp. 178-180.

83. Donoso, A. Parque Nacional Yasuní ha Despertado Gran Interés Científico. Ecuador. 2008. Available online: http://www.ambiente.gob.ec/wp-content/uploads/downloads/2012/07/ParqueNacional-Yasuní.pd (accessed on 4 December 2019).

84. Atkinson, R.; Flint, J. Accessing hidden and hard-to-reach populations: Snowball research strategies. Soc. Res. Update 2001, 33, 1-4.

85. Cohen, N.; Arieli, T. Field research in conflict environments: Methodological challenges and snowball sampling. J. Peace Res. 2011, 48, 423-435. [CrossRef] 
86. Kirchherr, J.; Charles, K. Enhancing the sample diversity of snowball samples: Recommendations from a research project on anti-dam movements in Southeast Asia. PLoS ONE 2018, 13, e0201710. [CrossRef]

87. Vanclay, F.; Baines, J.T.; Taylor, C.N. Principles for ethical research involving humans: Ethical professional practice in impact assessment Part I. Impact Assess. Proj. Apprais. 2013, 31, 243-253. [CrossRef]

88. Smith, L.T. Decolonizing Methodologie: Research and Indigenous Peoples; Zed Books: London, UK, 1999.

89. Vasquez-Fernandez, A.M.; Hajjar, R.; Shuñaqui Sangama, M.I.; Lizardo, R.S.; Pérez Pinedo, M.; Innes, J.L.; Kozak, R.A. Co-creating and Decolonizing a Methodology Using Indigenist Approaches: Alliance with the Asheninka and Yine-Yami Peoples of the Peruvian Amazon. ACME Int. J. Crit. Geogr. 2017, 17, 720-749.

90. Wilson, T. Visualising the demographic factors which shape population age structure. Demogr. Res. 2016, 35, 867-890. [CrossRef]

91. Milovanovic, V.; Smutka, L. Populating Aging in Rural India: Implication for Agriculture and Smallholder Farmers. J. Popul. Ageing 2019, 13, 305-323. [CrossRef]

92. Book Review: Donald Rowland, Demographic Methods and Concepts, Oxford: Oxford University Press, 2003, xiv + 546 pp. Eur. J. Popul. 2004, 20, 291-292. [CrossRef]

93. Hinde, P.R.A. Demographic Methods. Population 2001, 56, 478. [CrossRef]

94. Holdsworth, C.; Finney, N.; Marshall, A.; Norman, P. Population and Society; Sage: London, UK, 2013.

95. Häni, F.; Stämpfli, A.; Tello, J.R.; Braga, F. Sustainability Assessment of Six Brazilian Coffee Farms in Bahia and Minas Gerais; Working Paper; Swiss College of Agriculture: Zollikofen, Switzerland; University of Applied Sciences Bern: Bern, Switzerland; University of Guelph: Guelph, ON, Canada, 2004.

96. Porsche, H.; Fischer, M.; Braga, F.; Häni, F. Introduction of the sustainability assessment tool RISE into Canadian agriculture. Work. Pap. J. Univ. Guelph 2004, 11, 11-19.

97. Grenz, J.; Thalmann, C.; Stämpfli, A.; Studer, C.; Häni, F. RISE—A method for assessing the sustainability of agricultural production at farm level. Rural Dev. News 2009, 1, 5-9.

98. Grenz, J.; Mainiero, R.; Schoch, M.; Sereke, F.; Stalder, S.; Thalmann, C.; Wyss, R. RISE 3.0-Manual. Sustainability Themes and Indicators; HAFL: Zollikofen, Switzerland, 2016; p. 96.

99. RISE, Response-Inducing Sustainability Evaluation. Version 3.0. 2000. Available online: http://rise.shl.bfh.ch (accessed on 10 October 2018).

100. Pardo, C.E.; Del Campo, P.C. Combinación de métodos factoriales y de análisis de conglomerados en R: El paquete FactoClass. Revista Colombiana Estadística 2007, 30, 231-245.

101. Afifi, A.; Clark, V.; May, S. Practical Multivariate Analysis; Chapman \& Hall/CRC Texts in Statistical Science: London, UK, 2012.

102. González de Miguel, C.; Hernández Díaz-Ambrona, C.G.; Postigo Sierra, J.L. Evaluación de la sostenibilidad agraria. El caso de La Concordia (Nicaragua); Ingeniería Sin Fronteras, Asociación para el Desarrollo: Barcelona, Spain, 2009.

103. Ward, J.H., Jr. Hierarchical grouping to optimize an objective function. J. Am. Stat. Assoc. 1963, 58, $236-244$. [CrossRef]

104. Perez, C. Técnicas Estadísticas con SPSS; Prentice Hall: New Jersey, NJ, USA, 2001.

105. Cuadras, C. Nuevos Mètodos de Analisis Multivariante; CMC Editions: Vancouver, BC, Canada, 2007.

106. Leech, N.L.; Barrett, K.C.; Morgan, G.A. IBM SPSS for Intermediate Statistics: Use and Interpretation; Routledge: New York, NY, USA, 2014.

107. Davis, J.; Sellers, S.; Gray, C.; Bilsborrow, R. Indigenous Migration Dynamics in the Ecuadorian Amazon: A Longitudinal and Hierarchical Analysis. J. Dev. Stud. 2017, 53, 1849-1864. [CrossRef]

108. INEC. Censo de Población y Vivienda; INEC: Quito, Ecuador, 2010.

109. Jarrín-V, P.S.; Carrillo, L.T.; Zamora, G. Demografía y transformación territorial: Medio siglo de cambio en la región amazónica de Ecuador. EUTOPÍA. Revista Desarrollo Econ. Territorial 2017, 12, 81-100. [CrossRef]

110. McSweeney, K.; Arps, S. A “demographic turnaround": The rapid growth of indigenous populations in lowland Latin America. Lat. Am. Res. Rev. JSTOR 2005, 40, 3-29. [CrossRef]

111. Bremner, J.; Bilsborrow, R.; Feldacker, C.; Holt, F.L. Fertility beyond the frontier: Indigenous women, fertility, and reproductive practices in the Ecuadorian Amazon. Popul. Environ. 2009, 30, 93-113. [CrossRef]

112. Wurtz, H. Indigenous women of Latin America: Unintended pregnancy, unsafe abortion, and reproductive health outcomes. Pimatisiwin 2012, 10, 271. [PubMed] 
113. Engelman, R.; Bremner, J.; De Souza, R.M.; Mogelgaard, K. Indigenous population, fertility, and reproductive intention in the lowland neotropics: Response to McSweeney. Conserv. Biol. 2006, 20, 1315-1317. [CrossRef] [PubMed]

114. McSweeney, K. Indigenous population growth in the lowland Neotropics: Social science insights for biodiversity conservation. Conserv. Biol. 2005, 19, 1375-1384. [CrossRef]

115. Borman, R. Cofan: Story of the forest people and the outsiders. Cult. Surv. Q. 1999, 23, 48-50.

116. Macdonald, T., Jr. Ethnicity and Culture amidst New "Neighbors": The Runa of Ecuador's Amazon Basin; Allyn and Bacon: Boston, MA, USA, 1999.

117. Rival, L.M. Trekking through History: The Huaorani of Amazonian Ecuador; Columbia University Press: New York, NY, USA, 2002.

118. Rudel, T.K.; Bates, D.; Machinguiashi, R. Ecologically noble Amerindians? Cattle ranching and cash cropping among Shuar and colonists in Ecuador. Lat. Am. Res. Rev. 2002, 37, 144-159.

119. Sierra, R.; Rodriguez, F.; Losos, E. Forest resource use change during early market integration in tropical rain forests: The Huaorani of upper Amazonia. Ecol. Econ. 1999, 30, 107-119. [CrossRef]

120. Pichón, F.J. Settler households and land-use patterns in the Amazon frontier: Farm-level evidence from Ecuador. World Dev. 1997, 25, 67-91. [CrossRef]

121. Murphy, L.L. Colonist Farm Income, Off-Farm Work, Cattle, Differentiation in Ecuador's Northern Amazon. Hum. Org. 2001, 60, 67-79. [CrossRef]

122. Murphy, L.; Bilsborrow, R.; Pichón, F. Poverty and prosperity among migrant settlers in the Amazon rainforest frontier of Ecuador. J. Dev. Stud. 1997, 34, 35-65. [CrossRef]

123. West, P. Conservation is Our Government Now: The Politics of Ecology in Papua New Guinea; Duke University Press: Durham, UK, 2006.

124. Sterling, E.J.; Betley, E.; Sigouin, A.; Gomez, A.; Toomey, A.; Cullman, G.; Malone, C.; Pekor, A.; Arengo, F.; Blair, M.; et al. Assessing the evidence for stakeholder engagement in biodiversity conservation. Biol. Conserv. 2017, 209, 159-171. [CrossRef]

125. Reimaan National Planning Team Reimaanlok. Looking to the Future: National Conservation Area Plan for the Marshall Islands; N. Baker: Melbourne, MEL, Australia, 2008.

126. Preuss, K.; Dixon, M. 'Looking after country two-ways': Insights into indigenous community-based conservation from the Southern Tanami. Ecol. Manag. Restor. 2012, 13, 2-15. [CrossRef]

127. Leenhardt, P.; Teneva, L.; Kininmonth, S.; Darling, E.; Cooley, S.; Claudet, J. Challenges, insights and perspectives associated with using social-ecological science for marine conservation. Ocean Coast. Manag. 2015, 115, 49-60. [CrossRef]

128. Ens, E.J. Vital Landscapes, Indigenous Futures. In People on Country; Altman, J., Kerin, S., Eds.; The Federation Press: Leichhardt, SYD, Australia, 2012; pp. 45-64.

129. Ens, E.J.; Daniels, C.; Nelson, E.; Roy, J.; Dixon, P. Creating multifunctional landscapes: Using exclusion fences to frame feral ungulate management preferences in remote Aboriginal-owned Northern Australia. Biol. Conserv. 2016, 197, 235-246. [CrossRef]

130. Boserup, E. The Conditions of Agricultural Growth: The Economics of Agrarin Change under Population Pressure; Transaction Publishers: New Brunswick, NJ, USA, 2011.

131. Schwartzman, S.; Moreira, A.; Nepstad, D. Rethinking tropical forest conservation: Perils in parks. Conserv. Biol. 2000, 14, 1351-1357. [CrossRef]

132. Hvalkof, S. Progress of the victims: Political ecology in the Peruvian Amazon. In Reimagining Political Ecology; Biersack, A., Greenberg, J.B., Eds.; Duke University Press: Durham, NC, USA, 2006.

133. Hicks, J.F.; Daly, H.E.; Davis, S.H.; de Freitas, M.D.L. Ecuador's Amazon Region; Development Issues and Options; World Bank Discussion Paper 75; World Bank: Washington, DC, USA, 1990.

134. Mainville, N.; Webb, J.; Lucotte, M.; Davidson, R.; Betancourt, O.; Cueva, E.; Mergler, D. Decrease of soil fertility and release of mercury following deforestation in the Andean Amazon, Napo River Valley, Ecuador. Sci. Total Environ. 2006, 368, 88-98. [CrossRef]

135. Torres, B.; Bilsborrow, R.; Barbieri, A.; Torres, A. Changes in income strategies of rural households in the Northern Ecuadorian Amazon. Revista Amazónica Ciencia Tecnologıa 2014, 3, 221-257.

136. Hoffmann, U. Assuring Food Security in Developing Countries under the Challenges of Climate Change: Key Trade and Development Issues of a Fundamental Transformation of Agriculture. UNCTAD Discussion Papers. 2011, p. 50. Available online: http://www.unctad.org (accessed on 23 July 2020). 
137. Nicholls, C. Enfoques agroecologicos para incrementar la resiliencia de los sistemas agricolas al cambio climático. In Agroecología y Resiliencia Socioecológica Adaptándose al Cambio Climático; Nicholls, C., Rios, L., Altieri, M., Eds.; Socla: Medellin, Colombia, 2013; pp. 18-29.

138. Montagnini, F.; Nair, P.K.R. Carbon sequestration: An underexploited environmental benefit of agroforestry systems. Agrofor. Syst. 2004, 1, 281-295.

139. Stückelberger, C. Das Konzept der Nachhaltigen Entwicklung Um Zwei Dimensionen Erweitern; Verlag Paul Haupt: Bern, Switzerland, 1999; pp. 103-122.

140. Loaiza, T.; Nehren, U.; Gerold, G. REDD+ and incentives: An analysis of income generation in forest-dependent communities of the Yasuní Biosphere Reserve, Ecuador. Appl. Geogr. 2015, 62, 225-236. [CrossRef]

141. Guzmán Gallegos, M.A. Para Que la Yuca Beba Nuestra Sangre: Trabajo, Género y Parentesco en Una Comunidad Quichua de la Amazonía Ecuatoriana; Abya-Yala: Quito, Ecuador, 1997.

142. Martínez Novo, R. Del tiempo insostenible y del sentido del tiempo en las comunidades kichwa canelos. Desacatos 2012, 40, 111-126.

143. Pérez, C.V.; Bilsborrow, R.; Torres, B. Income diversification of migrant colonists vs. indigenous populations: Contrasting strategies in the Amazon. J. Rural Stud. 2015, 42, 1-10. [CrossRef]

144. Mejía, E.; Pacheco, P.; Muzo, A.; Torres, B. Smallholders and timber extraction in the Ecuadorian Amazon: Amidst market opportunities and regulatory constraints. Int. For. Rev. 2015, 17, 38-50. [CrossRef]

145. EP. Gestión Social. Reporte Gerencial 2018, Petroamazonas EP. 2018. Available online: https://www. petroamazonas.gob.ec/wp-content/uploads/downloads/2019/04/INF-PRC-POR-PROVINCIA_2018.pdf (accessed on 20 August 2020).

146. Durango-Cordero, J.; Saqalli, M.; Laplanche, C.; Locquet, M.; Elger, A. Spatial Analysis of Accidental Oil Spills Using Heterogeneous Data: A Case Study from the North-Eastern Ecuadorian Amazon. Sustainability 2018, 10, 4719. [CrossRef]

147. Vargas, G.C.; Au, W.W.; Izzotti, A. Public health issues from crude-oil production in the Ecuadorian Amazon territories. Sci. Total Environ. 2020, 719, 134647. [CrossRef] [PubMed]

148. Webb, J.; Coomes, O.T.; Mergler, D.; Ross, N.A. Levels of 1-hydroxypyrene in urine of people living in an oil producing region of the Andean Amazon (Ecuador and Peru). Int. Arch. Occup. Environ. Health 2018, 91, 105-115. [CrossRef]

149. Burgherr, P.; Eckle, P.; Hirschberg, S. Comparative assessment of severe accident risks in the coal, oil and natural gas chains. Reliab. Eng. Syst. Saf. 2012, 105, 97-103. [CrossRef]

150. Burgherr, P.; Hirschberg, S. Comparative risk assessment of severe accidents in the energy sector. Energy Policy 2014, 74, S45-S56. [CrossRef]

151. UN. Universal Declaration of Human Rights; United Nations: New York, NY, USA, 1948; Available online: http://www.un.org/en/documents/udhr/index.shtml (accessed on 20 August 2020).

152. Suárez-Torres, J.; Suárez-López, J.R.; López-Paredes, D.; Morocho, H.; Cachiguango-Cachiguango, L.E.; Dellai, W. Agroecology and Health: Lessons from Indigenous Populations. Curr. Envir. H 2017, 4, $244-251$. [CrossRef]

153. Mistry, J.; Berardi, A. Bridging indigenous and scientific knowledge. Science 2016, 352, 1274-1275. [CrossRef]

154. Tengö, M.; Hill, R.; Malmer, P.; Raymond, C.M.; Spierenburg, M.; Danielsen, F.; Elmqvist, T.; Folke, C. Weaving knowledge systems in IPBES, CBD and beyond-lessons learned for sustainability. Curr. Opin. Environ. Sustain. 2017, 26, 17-25. [CrossRef]

155. Gratani, M.; Butler, J.R.A.; Royee, F.; Valentine, P.; Burrows, D.; Canendo, W.I.; Anderson, A.S. Is validation of indigenous ecological knowledge a disrespectful process? A case study of traditional fishing poisons and invasive fish management from the Wet Tropics, Australia. Ecol. Soc. 2011, 16, 25. [CrossRef]

156. Berkes, F. Sacred Ecology, 4th ed.; Routledge: New York, NY, USA, 2018.

157. Donatuto, J.; Grossman, E.E.; Konovsky, J.; Grossman, S.; Campbell, L.W. Indigenous community health and climate change: Integrating biophysical and social science indicators. Coast. Manag. 2014, 42, 355-373. [CrossRef]

158. Vasco, C.; Bilsborrow, R. Contribution of off-farm employment to income of indigenous and mestizo households in the Ecuadorian Amazon. Economía Agraria Recursos Natur. Agricult. Res. Econ. 2016, 16, 5-18. 
159. Ospina, V.; Torres, B.; Köthke, M.; Knapp, G.M.; Fisher, R.V.; Günter, S. Sistema socio-productivo y modelo de gobernanza en la comunidad kichwa "Shiwakucha", Pastaza, Ecuador. Revista Amazónica Ciencia y Tecnología 2017, 6, 126-149.

160. McNeely, J.A.; Schroth, G. Agroforestry and Biodiversity Conservation-Traditional Practices, Present Dynamics, and Lessons for the Future. Biodivers. Conserv. 2006, 15, 549-554. [CrossRef]

161. Sahoo, G.; Wani, A.M. Multifunctional agroforestry systems in India for livelihoods. Ann. Horticult. 2019, 12, 139-149. [CrossRef]

162. Almeida e Silva, J.V.; Gomes, F.A.; de Freitas, H.J.; Barbosa, M.; da Silva, J.C.T. Levels of cupuaçu seed by-product in feedstuff for free-range broilers reared in the Western Amazon. Arquivos Ciências Veterinárias Zoologia UNIPAR 2017, 20, 1-7.

163. Chauhan, B.S.; Johnson, D.E. The role of seed ecology in improving weed management strategies in the tropics. Adv. Agron. 2010, 105, 221-262.

164. Lazcano, C.; Gómez-Brandón, M.; Revilla, P.; Domínguez, J. Short-term effects of organic and inorganic fertilizers on soil microbial community structure and function. Biol. Fertil. Soils 2013, 49, 723-733. [CrossRef]

165. Alegre, J.; Lao, C.; Silva, C.; Schrevens, E. Recovering degraded lands in the Peruvian Amazon by cover crops and sustainable agroforestry systems. Peruv. J. Agron. 2017, 1, 1-7. [CrossRef]

166. Gordon, L.J.; Finlayson, C.M.; Falkenmark, M. Managing water in agriculture for food production and other ecosystem services. Agricult. Water Manag. 2010, 97, 512-519. [CrossRef]

167. León Alvear, V.; Torres, B.; Luna, M.; Torres, A.; Ramírez, P.; Andrade-Yucailla, V.; Muñoz-Rengifo, J.C.; Heredia, R.M. Percepción sobre cambio climático en cuatro comunidades orientadas a la ganadería bovina en la zona central de los Andes Ecuatorianos. Livest. Res. Rural. Develop. 2020, 32, 165.

168. Toulkeridis, T.; Tamayo, E.; Simón, D.; Merizalde, M.J.; Reyes, D.F.; Viera, M.; Heredia, M. Climate Change according to Ecuadorian academics-Perceptions ver-sus facts. Granja Revista Ciencias Vida 2020, 31, $21-49$. [CrossRef]

169. Torres, B.; Starnfeld, F.; Vargas, J.C.; Ramm, G.; Chapalbay, R.; Rios, M.; Gómez, A.; Torricelli, Y.; Jurrius, I.; Tapia, A.; et al. Gobernanza Participativa en la Amazonía del Ecuador: Recursos Naturales y Desarrollo Sostenible; Universidad Estatal Amazónica: Puyo, Ecuador, 2013; 124p.

170. Lowan-Trudeau, G. Indigenous Environmental Education: The Case of Renewable Energy Projects. Educ. Stud. 2017, 53, 601-613. [CrossRef]

171. Heredia, M.; Bravo, C.; Torres, B.; Alemán, R. Innovación para el fortalecimiento de capacidades sobre sostenibilidad de los recursos naturales en poblaciones indígenas y mestizas-Colonas: Reserva de Biosfera Yasuní. Revista Ibérica Sistemas Tecnologias Informação 2020, 25, 103-116.

172. García, N.; Galeano, G.; Mesa, L.; Castaño, N.; Balslev, H.; Bernal, R. Management of the palm Astrocaryum chambira Burret (Arecaceae) in northwest Amazon. Acta Bot. Brasilica 2015, 29, 45-57. [CrossRef]

173. Innerhofer, S.; Bernhardt, K.G. Ethnobotanic garden design in the Ecuadorian Amazon. Biodivers. Conserv. 2011, 20, 429-439. [CrossRef]

174. Turner, N.J.; Łuczaj, Ł.J.; Migliorini, P.; Pieroni, A.; Dreon, A.L.; Sacchetti, L.E.; Paoletti, M.G. Edible and tended wild plants, traditional ecological knowledge and agroecology. Crit. Rev. Plant Sci. 2011, 30, 198-225. [CrossRef]

175. Leeuwis, C. Communication for Rural Innovation: Rethinking Agricultural Extension; John Wiley \& Sons: Amsterdam, The Netherlands, 2013.

176. Hart, M.B.; Moore, M.J.; Laverty, M. Improving Indigenous health through education. Med. J. Aust. 2017, 207, 11-12. [CrossRef]

177. Cortina, R. The Education of Indigenous Citizens in Latin America; Multilingual Matters: Bristol, USA, 2013; Volume 95.

178. Heredia-R, M.; Falconí, A.K.; Barreto, D.; Amores, K.; Silva, J.H.; Torres, B. Conductas sustentables sobre el marco de evaluación SAFA-FAO: Un aporte para poblaciones rurales vulnerables de la Amazonía. Revista Ibérica Sistemas Tecnologias Informação 2020, 33, 312-326.

179. Lawlor, K.; Madeira, E.M.; Blockhus, J.; Ganz, D.J. Community participation and benefits in REDD+: A review of initial outcomes and lessons. Forests 2013, 4, 296-318. [CrossRef]

180. Chhatre, A.; Lakhanpal, S.; Larson, A.M.; Nelson, F.; Ojha, H.; Rao, J. Social safeguards and co-benefits in REDD+: A review of the adjacent possible. Curr. Opin. Environ. Sustain. 2012, 4, 654-660. [CrossRef] 
181. Arnés, E.; Díaz-Ambrona, C.G.; Marín-González, O.; Astier, M. Farmer Field Schools (FFSs): A tool empowering sustainability and food security in peasant farming systems in the Nicaraguan Highlands. Sustainability 2018, 10, 3020.

182. Marinello, F.; Pezzuolo, A.; Chiumenti, A.; Sartori, L. Technical analysis of unmanned aerial vehicles (drones) for agricultural applications. In Proceedings of the Engineering for Rural Development, Jelgava, Latvia, 25-27 May 2016; Volume 15.

183. Aker, J.C. Dial "A" for agriculture: A review of information and communication technologies for agricultural extension in developing countries. Agricult. Econ. 2011, 42, 631-647. [CrossRef]

184. Mittal, S.; Gandhi, S.; Tripathi, G. Socio-Economic Impact of Mobile Phones on Indian Agriculture; Indian Council for Research on International Economic Relations (ICRIER): New Delhi, India, 2010.

185. Barreto-Álvarez, D.E.; Heredia-Rengifo, M.G.; Padilla-Almeida, O.; Toulkeridis, T. Multitemporal Evaluation of the Recent Land Use Change in Santa Cruz Island, Galapagos, Ecuador. In Information and Communication Technologies, TICEC 2020; Communications in Computer and Information Science; Springer: Cham, Switzerland, 2020; Volume 1307. [CrossRef]

Publisher's Note: MDPI stays neutral with regard to jurisdictional claims in published maps and institutional affiliations.

(C) 2020 by the authors. Licensee MDPI, Basel, Switzerland. This article is an open access article distributed under the terms and conditions of the Creative Commons Attribution (CC BY) license (http://creativecommons.org/licenses/by/4.0/). 